\title{
Mid-term post-fire losses of nitrogen and phosphorus by overland flow in two contrasting eucalypt stands in north-central Portugal
}

\author{
D. Serpa *, R.V. Ferreira, A.I. Machado, M.A. Cerqueira, J.J. Keizer \\ Department of Environment and Planning E' CESAM, University of Aveiro, Campus de Santiago, 3810-193 Aveiro, Portugal
}

\section{H I G H L I G H T S}

- Post-fire $\mathrm{N}$ and P exports were evaluated in recently burnt eucalypt hillslopes.

- Higher $\mathrm{N}$ and $\mathrm{P}$ exports were found at north than south-facing hillslopes.

- Land management practices can exacerbate the effect of fires on nutrient exports.

- Wildfires can be a source of P contamination to surface water bodies.

\section{A R T I C L E I N F O}

\section{Article history:}

Received 28 September 2019

Received in revised form 27 November 2019

Accepted 28 November 2019

Available online 2 December 2019

Editor: Paulo Pereira

\section{Keywords:}

Wildfires

Nutrient exports

Runoff

Slope aspect

Land management

Mediterranean region

\section{G R A P H I C A L A B S T R A C T}

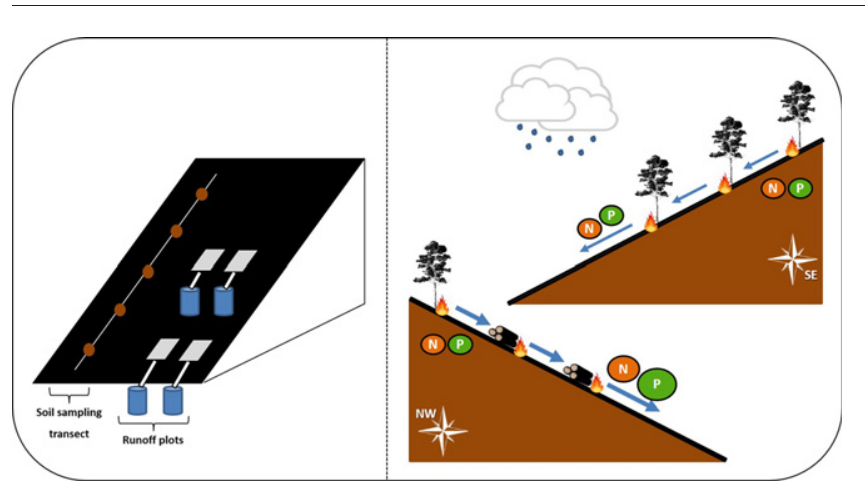

\section{A B S T R A C T}

Wildfires affect vast areas of Mediterranean forests, thereby triggering changes in hydrological and geomorphological processes that can negatively affect both terrestrial and aquatic ecosystems. Although several studies have evaluated the post-fire hydrological and erosive response in burnt forest areas, an important knowledge gap remains with respect to nutrient mobilization by overland flow. To address this gap, a recently burnt area was selected near the Ermida village (north-central Portugal). The study area was instrumented shortly after a wildfire that occurred in July 2010, to evaluate the export of dissolved (nitrate $-\mathrm{NO}_{3}-\mathrm{N}$ and orthophosphate $-\mathrm{PO}_{4}-\mathrm{P}$ ) and total nitrogen (TN) and phosphorus (TP) forms by overland flow. This was done in two burnt eucalyptus plantations due to their contrasting slope aspects (south-east vs. north-west). Bounded micro-plots were installed in August 2010 and monitored over two years. During this period, overland flow samples were collected on a 1to 2-weekly basis, depending on the occurrence of rain. Results showed that the north west-facing slope (BE$\mathrm{N}$ ) presented higher nutrient losses than the south east-facing slope (BE-S), contradicting the findings of previous studies in the Mediterranean region. A logging operation that had taken place at the BE-N site shortly before the fire might account for these findings, by causing soil compaction and/or reducing the protective vegetation and litter cover. TN and TP exports were particularly pronounced during the first four months following the wildfire. After this initial period, further peaks in TN and TP exports occurred sporadically, mainly associated to intense rainfall events. The observed mid-term post-fire nutrient losses not only suggested a threat to the soil nutrient balance of Mediterranean eucalypt forests but also a potential risk of eutrophication of downstream water bodies. (c) 2019 Elsevier B.V. All rights reserved.

\footnotetext{
* Corresponding author.

E-mail address: dalila.serpa@ua.pt (D. Serpa).
} 


\section{Introduction}

The warmer and drier conditions forecasted for the Mediterranean region during the 21 st century are expected to change the region's wildfire regimes (Turco et al., 2014; Viedma et al., 2015). Although fire is a natural element, more severe and recurrent fires can pose a serious threat to the ability of forest ecosystems to regenerate spontaneously and, thereby, to the services that these ecosystems provide, including the regulating functions of the water cycle and protection against erosion (Mayor et al., 2016; Vallejo and Alloza, 2015).

Depending on fire severity, fire-induced changes in vegetation and soil physical (e.g. decrease in soil porosity and decrease in water holding capacity and infiltration), chemical (e.g. decrease in soil organic matter) and biological (e.g. reduction of soil microbial biomass and activity) properties can greatly affect the nutrient cycles, both directly and indirectly, through enhanced post-fire exports by runoff (Certini, 2005; Costa et al., 2014; Ferreira et al., 2016a, 2016b; Hosseini et al., 2017; Knoepp et al., 2005; Machado et al., 2015; Moody et al., 2013). This is a major concern for the sustainable management of forest soils of Mediterranean hillslopes and mountains as these soils are often shallow and poor in nutrients (Caon et al., 2014; Ferreira et al., 2005; Mayor et al., 2016; Shakesby, 2011; Shakesby and Doerr, 2006). In the case of macronutrients such as nitrogen $(\mathrm{N})$ and phosphorus $(\mathrm{P})$ largely contained in the aboveground vegetation and litter pools, fires not only provoke direct losses through volatilization and particle emission but also lead to deposition in the form of ash and charcoal particles that are particularly prone to erosion by wind and, especially, water (Badía et al., 2014; Bodí et al., 2014; Caon et al., 2014; Certini, 2005; Knoepp et al., 2005; Neary et al., 1999).

Enhanced nutrient losses by runoff after fire are often strongly related to the lack of protective soil cover, resulting from the partial or complete consumption of vegetation and litter layer (Certini, 2005; Ferreira et al., 2005; Ferreira et al., 2016a, 2016b; Thomas et al., 1999, 2000a, 2000b; Shakesby, 2011). The decrease in interception by vegetation and litter not only enhances the erosive potential of rain (Certini, 2005) but also increases the effective rainfall intensity, increasing the likelihood of overland flow generation and the associated transport of ash, charcoal and soil particles as well as of nutrients in dissolved and particulate form (Caon et al., 2014; Certini, 2005; Ferreira et al., 2005; Pausas et al., 2008; Shakesby, 2011; Thomas et al., 1999, 2000a, 2000b; Wittenberg et al., 2014). Aside from decreasing the on-site nutrient pools (Caon et al., 2014; Certini, 2005; Pausas et al., 2008; Shakesby, 2011), runoff-induced nutrient losses enhance the risk of eutrophication to downstream water bodies and the associated deterioration of chemical and biological water quality (Abraham et al., 2017; Bladon et al., 2014; Emelko et al., 2016; Silins et al., 2014; Smith et al., 2011; Verkaik et al., 2013).

The existing knowledge of post-fire nutrient losses by runoff is still rather limited but suggests that these losses are highly variable, as they involve a complex interplay of a large number of factors, including: (i) fire regime, such as fire frequency, intensity, and severity (Bodí et al., 2014; Caon et al., 2014; Hosseini et al., 2017; Knoepp et al., 2005; Neary et al., 1999; Shakesby and Doerr, 2006); (ii) land cover and management, such as vegetation type and stand age (Caon et al., 2014; Cerdà and Doerr, 2008; Certini, 2005; Ferreira et al., 2016a, 2016b; Knoepp et al., 2005; Neary et al., 1999); (iii) terrain, including slope steepness and aspect (Bodí et al., 2014; Certini, 2005; Neary et al., 1999; Shakesby and Doerr, 2006); (iv) bedrock and soil type (Certini, 2005; Ferreira et al., 2016a, 2016b; Neary et al., 1999; Shakesby and Doerr, 2006); and (v) post-fire climate conditions, such as timing and intensity of rainfall events (Bodí et al., 2014; Certini, 2005; Neary et al., 1999; Shakesby and Doerr, 2006). This study specifically addresses the role of slope aspect and pre-fire forest management or, to be more specific, logging. Slope aspect determines the amount of solar radiation received by a hillslope, which, in turn, can affect pre-fire vegetation and soil properties, fire intensity and severity, and post-fire vegetation recovery
(Cerdà, 1998; Gabarrón-Galeote et al., 2013; Kutiel and Lavee, 1999; Sternberg and Shoshany, 2001; Wittenberg et al., 2014). Especially when involving heavy machinery that causes soil compaction and reduction of soil cover, post-fire forest management operations such as ploughing and logging have been found to enhance runoff and soil (fertility) losses (Fernández et al., 2007; Malvar et al., 2016; Thomas et al., 2000a, 2000b; Smith et al., 2012). These same operations can be expected to have similar impacts when carried out before a fire, with the extent of these impacts depending on the time-between the operation and fire (Malvar et al., 2016; Vieira et al., 2016).

Given this multitude of factors affecting post-fire nutrient mobilization, the existing literature does not allow a comprehensive understanding of $\mathrm{N}$ and $\mathrm{P}$ processes in burnt areas across the Mediterranean (Cancelo-González et al., 2013; DeBano et al., 1998; Díaz-Fierros et al., 1990; Lasanta and Cerdà, 2005; Ferreira et al., 2016a, 2016b; Santos et al., 2015). In the case of Portugal, nine scientific articles have quantified post-fire $\mathrm{N}$ and $\mathrm{P}$ exports by overland flow, focusing on the first 1 to 2 years following fire (Coelho et al., 2004; Hosseini et al., 2017; Ferreira et al., 1997, 2005; Ferreira et al., 2016a, 2016b; Thomas et al., 2000a, 2000b; Walsh et al., 1992). These studies concerned the two predominant and, at the same time, markedly fire-prone forest types in north and central Portugal, i.e. Maritime pine (Pinus pinaster Ait.) and eucalypt (Eucalyptus globulus Labill.) plantations. Six of these studies, however, were limited to nutrient losses in dissolved form (Coelho et al., 2004; Ferreira et al., 1997, 2005; Thomas et al., 2000a, 2000b; Walsh et al., 1992), ignoring the losses in particulate form associated to the transport of ash, charcoal and soil particles. Nonetheless, the findings of Ferreira et al. (2016a, 2016b) suggested that particulate losses substantially exceeded dissolved losses, at least during the initial 6 months following the wildfire.

The present study complements the studies of Ferreira et al. (2016a, 2016b) which quantified total $\mathrm{N}$ and $\mathrm{P}$ exports by post-fire overland flow in the same burnt area but addressed the role of parent material, comparing a burnt eucalypt stand on granite vs. a burnt eucalypt stand on schist, as well as the role of land cover, comparing a burnt eucalypt stand vs. a burnt Maritime Pine stand. Furthermore, Ferreira et al. (2016a, 2016b) studied a different stand than the present study and, most importantly, could only quantify short-term exports, due to the conversion of the study slopes to bench terraces for a new eucalypt plantation some six months after the fire. This study focused on eucalypt forests, as it is the predominant forest type in north-central Portugal and it produced greater $\mathrm{N}$ and $\mathrm{P}$ losses than the Maritime pine forest in Ferreira et al. (2016a, 2016b). The specific objectives were then to: i) quantify $\mathrm{N}$ and $\mathrm{P}$ exports at the micro-plot scale for two eucalypt plantations with contrasting slope aspects (south-east vs. north-west), as aspect was expected to be a key factor in post-fire nutrient mobilization; ii) analyze the evolution of post-fire $\mathrm{N}$ and $\mathrm{P}$ losses with time-since fire, as especially total export was expected to closely follow the typically fast decrease in erosion with time-since fire in the region; iii) relate $\mathrm{N}$ and $\mathrm{P}$ exports to their contents and stocks in the ash layer and topsoil, for a better understanding of the $\mathrm{N}$ and $\mathrm{P}$ cycles; and iv) evaluate if the $\mathrm{N}$ and $\mathrm{P}$ levels in overland flow posed a risk of contamination for downstream water bodies.

\section{Materials and methods}

\subsection{Study area and sites}

The study area was located near the Ermida village, in the Sever do Vouga municipality, north-central Portugal (Fig. 1). On July 26, 2010, the area was affected by a wildfire that consumed roughly 300 ha of forest (DUDF, 2011). Prior to the fire, the area was predominantly covered by eucalypt plantations (Eucalyptus globulus Labill.) but it also included some Maritime pine stands (Pinus pinaster Ait.). Fire severity was, on overall, moderate, since the ash was black, the litter layer and understory vegetation were completely consumed by fire and tree crowns 


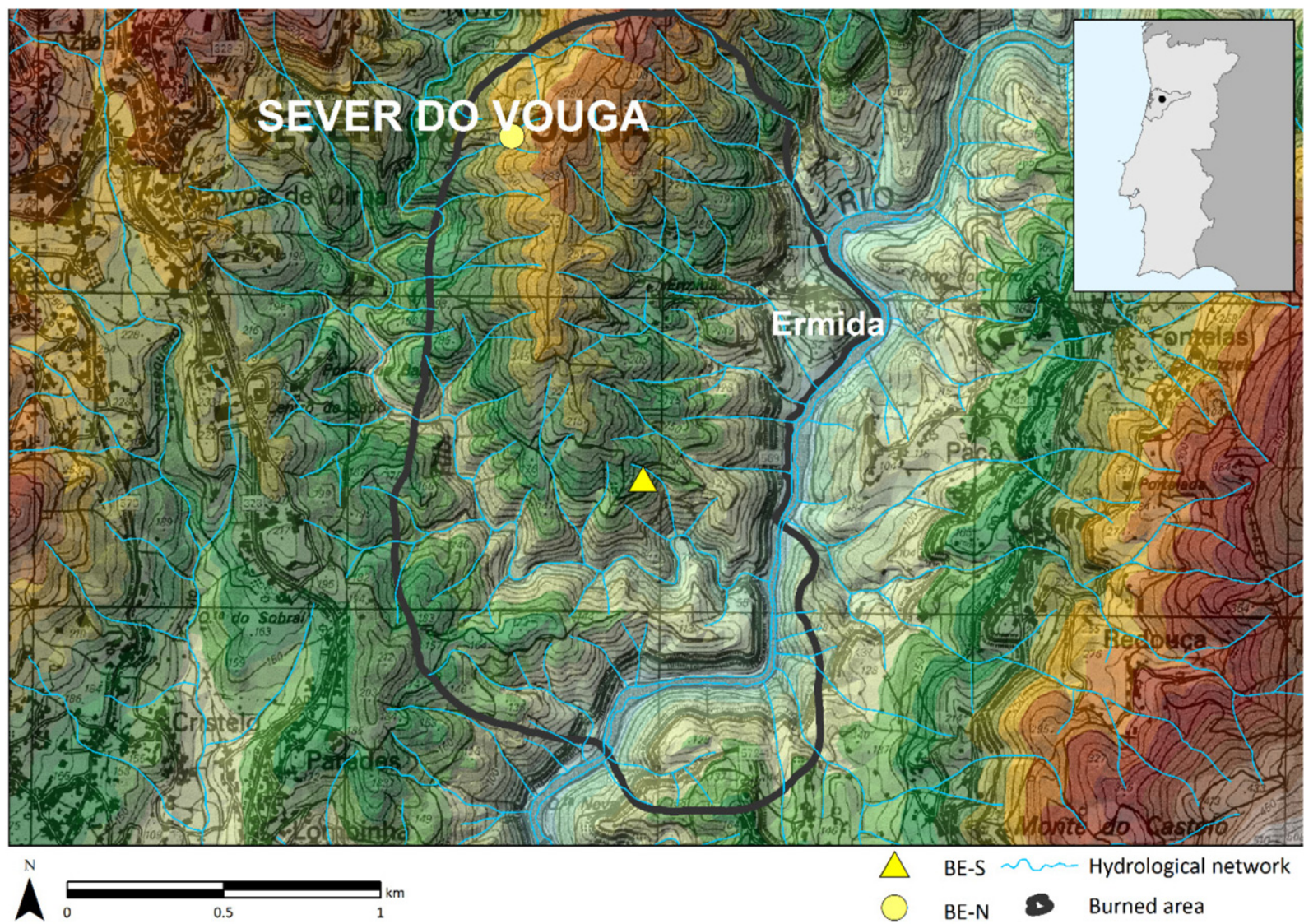

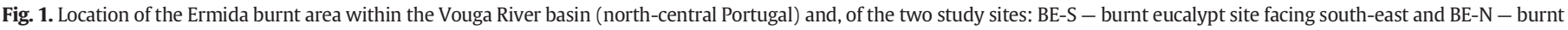
eucalypt site facing north-west.

were only partially scorched (Shakesby and Doerr, 2006). Within the burnt area, two hillslopes with eucalypt plantations were selected due to their contrasting slope aspect (south-east vs. north-west) but, at the same time, being comparable in terms of fire severity (i.e. moderate) and slope angle $\left(20^{\circ}\right.$ vs. $\left.30^{\circ}\right)$ (Fig. 1 ; Table 1$)$. At the time of fire, the north-west facing slope (BE-N) had recently been logged but the logs themselves had not yet been extracted (Fig. 2). The presumed presence of dried-out logging residues on the forest floor at the time of the fire

Table 1

General description of the two study sites. BE-S - burnt eucalypt site facing south-east and BE-N - burnt eucalypt site facing north-west.

\begin{tabular}{lll}
\hline Slope & BE-S & BE-N \\
\hline $\begin{array}{l}\text { General characteristics } \\
\text { Forest type }\end{array}$ & $\begin{array}{l}\text { Eucalyptus globulus } \\
\text { Schist }\end{array}$ & $\begin{array}{l}\text { Eucalyptus globulus } \\
\text { Schist }\end{array}$ \\
Exposure & South-east & North-west \\
Geographical coordinates & $40^{\circ} 43^{\prime} 30^{\prime \prime} \mathrm{N}$ & $40^{\circ} 44^{\prime} 05^{\prime \prime} \mathrm{N}$ \\
& $8^{\circ} 20^{\prime} 57^{\prime \prime} \mathrm{W}$ & $8^{\circ} 21^{\prime} 15^{\prime \prime} \mathrm{W}$ \\
Elevation (m.a.s.l.) & 150 & 266 \\
Slope angle $\left(^{\circ}\right)$ & $20.0 \pm 2.0$ & $19.0 \pm 3.0$ \\
Slope length $(\mathrm{m})$ & 60 & 90 \\
Fire severity & Moderate & Moderate \\
Topsoil properties & & \\
[0-2] cm depth & & Sandy loam \\
Texture & Sandy clay loam & 71 \\
Sand fraction $(\%)$ & 67 & 10 \\
Silt fraction $(\%)$ & 9 & 18 \\
Clay fraction $(\%)$ & $28 \pm 4$ & $32 \pm 12$ \\
Organic matter $(\%)$ & $1.15 \pm 0.19$ & $0.88 \pm 0.13$ \\
[0-5] cm depth & &
\end{tabular}

could explain that the ash cover immediately after the fire was higher at this site than at the south-east facing site (BE-S) (Fig. 3).

The climate of the study area is classified as humid meso-thermal (Csb, according to the Köppen classification), with moderately dry but prolonged summers (DRA-Centro, 2002). The mean annual temperature at the nearest climate station (Castelo-Burgães: $40^{\circ} 51^{\prime} 10^{\prime \prime} \mathrm{N}, 8^{\circ}$ $22^{\prime} 44^{\prime \prime} \mathrm{W}$; $306 \mathrm{~m}$ a.s.l.) was $14.8^{\circ} \mathrm{C}$ (1991-2017; SNIRH, 2019), with average monthly temperatures ranging from $9.0^{\circ} \mathrm{C}$ in January to $21.0^{\circ} \mathrm{C}$ in July. Annual rainfall at the nearest rainfall station (Ribeiradio: $40^{\circ} 73^{\prime} 65^{\prime \prime}$ $\mathrm{N}, 8^{\circ} 30^{\prime} 08^{\prime \prime} \mathrm{W} ; 228 \mathrm{~m}$ a.s.l.) was, on average, $1655 \mathrm{~mm}$, but varied markedly between dry (960 mm) and wet $(2530 \mathrm{~mm})$ years (1991-2011; SNIRH, 2019).

The area belongs to the Hesperic Massif, one of the major physiographic units in the region (Ferreira, 1978). The parent material in the study area consists mainly of pre-Ordovician schists but included Hercynian granites at some locations (Pereira and FitzPatrick, 1995). Field descriptions of soil profiles revealed that soils are mainly Umbric skeletic leptosols (dystric) at the BE-S site and Umbric hyperskeletic leptosols (dystric) at the BE-N site (IUSS, 2015). The topsoil $(0-2 \mathrm{~cm}$ ) at the two sites was rather coarse, with a sandy-loam to sandy-clay loam texture and high organic matter content (28-32\%) (Table 1). The bulk density of the topsoil $(0-5 \mathrm{~cm}$ depth) was similar at the two sites, but slightly higher values were found at the BE-S (1.15 \pm $\left.0.19 \mathrm{~g} \mathrm{~cm}^{-3}\right)$ than at the BE-N slope $\left(0.88 \pm 0.13 \mathrm{~g} \mathrm{~cm}^{-3}\right)$.

\subsection{Experimental design and sample collection}

Each of the study sites was divided into two adjacent strips, running from the base to the top of the slope section (Fig. 4). One of the strips was used for repeated soil sampling and the other for installing microplots for measuring overland flow (Fig. 4). 

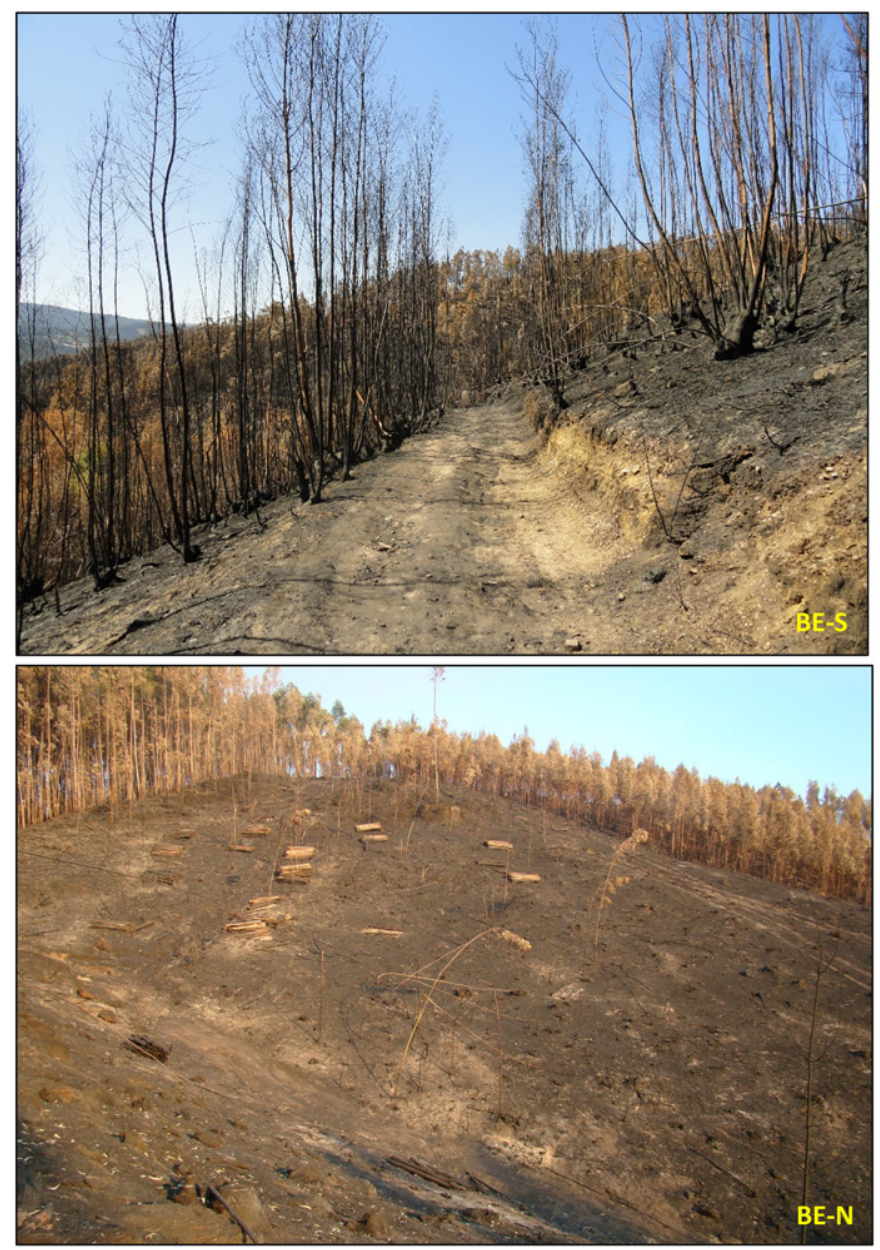

Fig. 2. View of the two study sites immediately after the wildfire. BE-S - burnt eucalypt site facing south-east and BE-N - burnt eucalypt site facing north-west. The bottom picture shows eucalypt tree logs that had felled shortly before the fire.

Soil sampling was limited to the upper $2 \mathrm{~cm}$ of the mineral soil, because moderate severity fires are known to principally affect the uppermost centimeters of the mineral soil (Badía et al., 2014; Fernández et al., 2013; Vega et al., 2014; Zavala et al., 2014). Soil samples were first collected on August 10, 2010, roughly two weeks after the wildfire; and then at 6-month intervals till the end of the monitoring period, on August 25,2012. At the first sampling occasion, ash samples were collected along with soil samples. Soil and ash layer sampling was done at five equally-distant points along a transect laid out from the base to the top of the slope section (Fig. 4), shifting the location of transect some 1-2 $\mathrm{m}$ across the slope in the subsequent sampling occasion. At each transect point, first the ash layer was collected in a plot of $0.25 \mathrm{~m}^{2}$ $(0.5 \mathrm{~m} \times 0.5 \mathrm{~m})$, and then the topsoil $(0-2 \mathrm{~cm}$ depth $)$ was collected at the center of this plot, over an area of $0.06 \mathrm{~m}^{2}(0.25 \mathrm{~m} \times 0.25 \mathrm{~m})$.

The study sites were instrumented with runoff plots on August 25, 2010 , before the occurrence of any significant post-fire rainfall. This involved the installation of two pairs of bounded micro-plots $\left(0.25-0.30 \mathrm{~m}^{2}\right)$ at each study site. One pair was installed at the base of the slope and the other pair halfway up the slope (Fig. 4), to evaluate if slope position would influence nutrient mobilization. The outlets of the micro-plots were connected, using a garden hose, to one or more high density polyethylene 30 L tanks to collect overland flow (Fig. 4). From August 25, 2010 to August 22, 2012, the runoff collected in the various tanks was measured at 1- to 2-weekly intervals, depending on the occurrence of rainfall. Whenever the volume in each tank exceeded $250 \mathrm{~mL}$, a sample was collected in a $500 \mathrm{~mL}$ polyethylene bottle that had been previously rinsed with hydrochloric acid $(\mathrm{pH}<2.0)$ and distilled

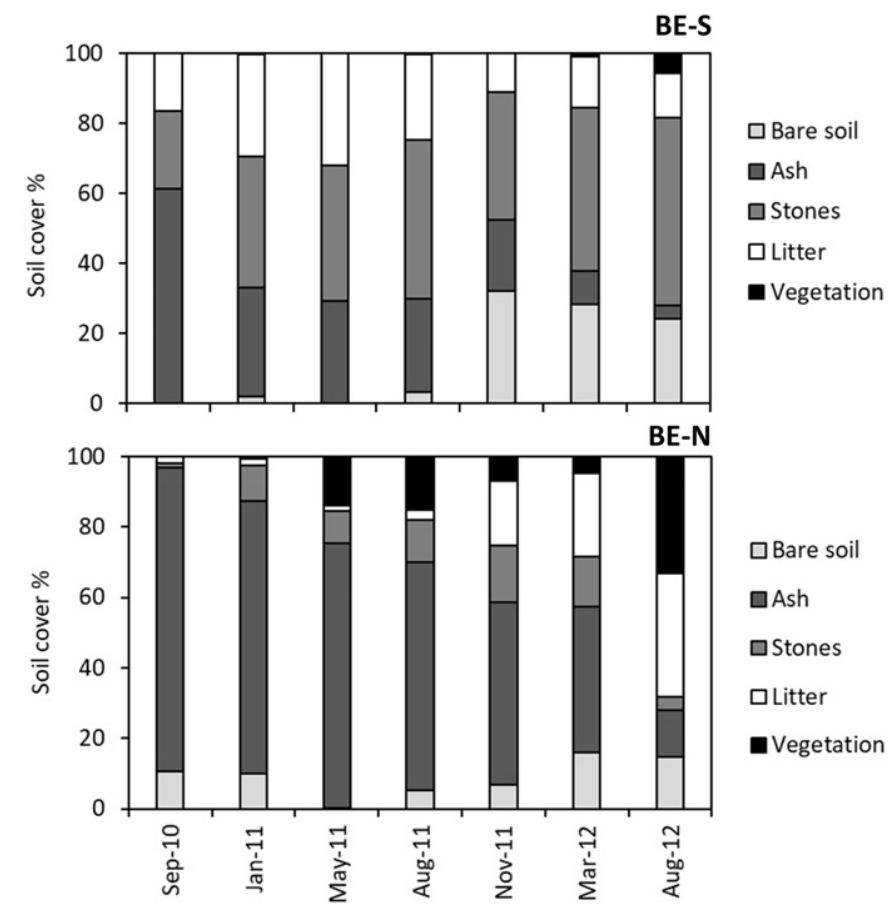

Fig. 3. Average ( $n=4)$ bare soil, ash, stone, litter and vegetation cover (\%) at the two study sites during the first two years after fire. BE-S - burnt eucalypt site facing south-east and BE-N - burnt eucalypt site facing north-west.

and deionized water. These samples were then transported to the laboratory in cool boxes and stored at $4{ }^{\circ} \mathrm{C}$ for no longer than $24 \mathrm{~h}$.

The 1- to 2-weekly field trips also involved measurement of rainfall accumulated in 4 storage gauges (in-house design) that had been installed across the study area by the middle of August 2010. Their main purpose, however, was to validate the automatic recordings of two tipping-bucket rainfall gauges (Pronamic Professional Rain Gauge with $0.2 \mathrm{~mm}$ resolution) that had been installed in close proximity to two of the storage gauges.

\subsection{Analytical methods}

Upon arrival at the laboratory, ash and soil samples were air dried and then sieved manually with a $2 \mathrm{~mm}$ sieve. Total nitrogen (TN) content, i.e. ammonium plus organic nitrogen, of the ash and soil samples was determined using the Kjeldahl method (Bremner, 1979). Available phosphorus $\left(\mathrm{P}_{\mathrm{av}}\right)$ content of ash and soil samples was determined by the Bray method (Bray and Kurtz, 1945), using a mixture of ammonium fluoride $(0.03 \mathrm{M})$ and hydrochloric acid $(0.025 \mathrm{M})$ as extractant. The extracted $\mathrm{P}$ was analyzed spectrophotometrically as orthophosphate by the molybdenum blue method (APHA, 1998). Aside from N and P, soil samples were also analyzed for: i) bulk density (0-5 cm depth), using the core method as described by Porta et al. (2003); ii) soil particle size, following the international method of mechanical analysis as defined by Guitián and Carballas (1976); and iii) organic matter, determined by loss on ignition at $550{ }^{\circ} \mathrm{C}$ for $4 \mathrm{~h}$, as described by Botelho da Costa (2004).

Overland flow samples were analyzed for dissolved inorganic $\left(\mathrm{NO}_{3}-\right.$ $\mathrm{N}$; and $\mathrm{PO}_{4}-\mathrm{P}$ ) and total (i.e. dissolved plus particulate) $\mathrm{N}$ and $\mathrm{P}$ forms, using a flow injection FIAstar ${ }^{\mathrm{TM}} 5000$ analyser (FOSS-Tecator). For determination of $\mathrm{NO}_{3}-\mathrm{N}$ and $\mathrm{PO}_{4}-\mathrm{P}$ concentrations in overland flow, $50 \mathrm{~mL}$ subsamples were filtered over $0.45 \mu \mathrm{m}$ Millipore ${ }^{\mathrm{TM}}$ membrane filters. For analysis of TN and TP concentrations, $50 \mathrm{~mL}$ subsamples were first subjected to an oxidative digestion, using peroxodisulphate/alkali (Oxisolv®, Merck), and then filtered over $0.45 \mu \mathrm{m}$ Millipore $₫$ membrane filters. The total suspended solids (TSS) concentration in overland flow samples was quantified gravimetrically through filtration of 

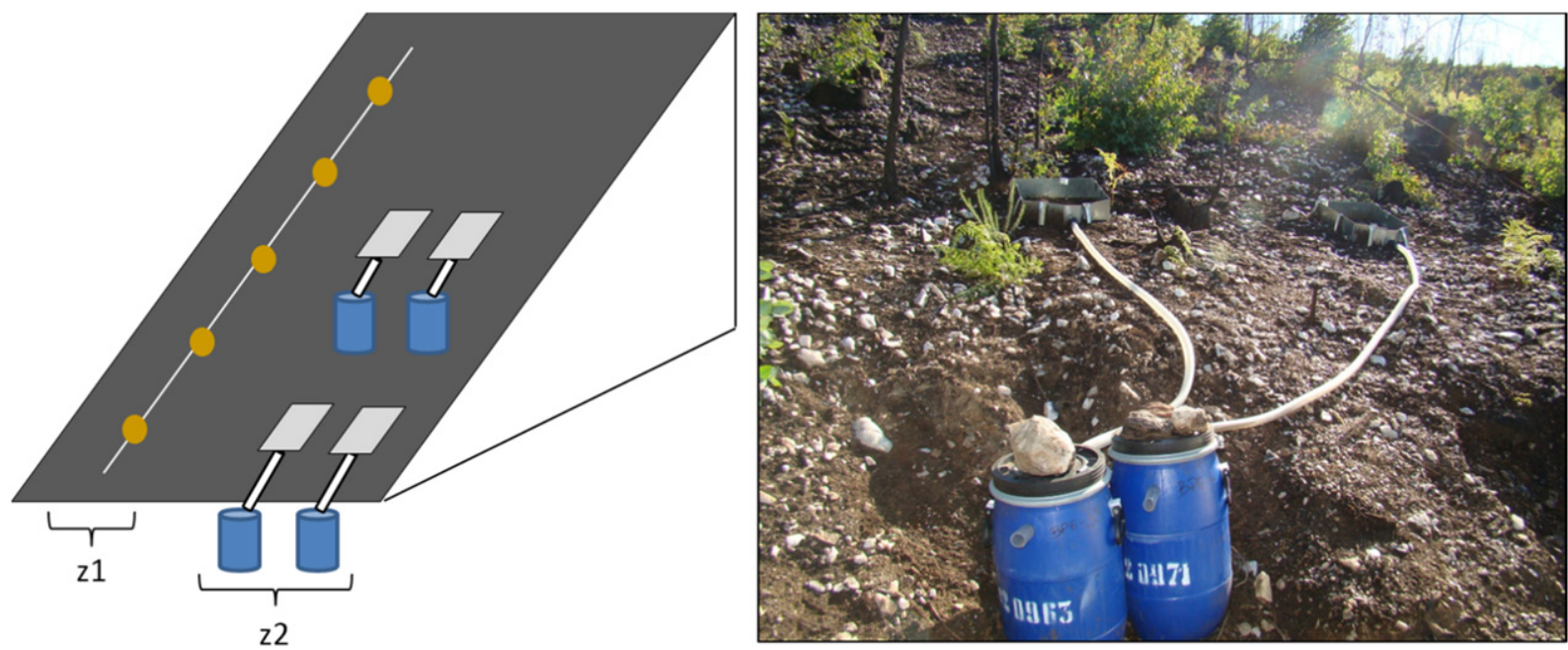

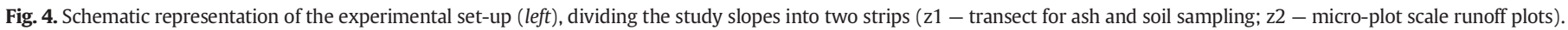
Example of the micro-plots located at the base of the slopes (right).

50-150 mL over a glass fiber filter, followed by drying to a constant weight at $105{ }^{\circ} \mathrm{C}$ (APHA, 1998).

\subsection{Data analysis}

Between-site differences in TN and $\mathrm{P}_{\mathrm{av}}$ contents in ash were evaluated by means of Student's t-tests, after checking for normality (Shapiro-Wilk test) and for homogeneity of variance (Brown-Forsythe test). Differences in the soil TN and $\mathrm{P}_{\mathrm{av}}$ contents between the two sites and sampling occasions were tested by means of two-way ANOVAs. If significant differences were found multi-comparison Tukey tests were performed. Whenever data did not meet the assumptions of normality and homogeneity of variance underlying ANOVA, logarithmic transformations were performed (Zar, 1999).

Differences in the exports of $\mathrm{NO}_{3}-\mathrm{N}, \mathrm{TN}, \mathrm{PO}_{4}-\mathrm{P}$ and TP between plots, sites and sampling dates were tested for significance by means of twoway Repeated Measures ANOVAs. These data, however, consistently failed to meet the normality assumption, even for a range of typical data transformations, so a general linear model was applied. Two-way Repeated Measures ANOVAs were also used to test differences in overland flow and sediment losses between plots, sites and sampling dates. As overland flow and erosion data also failed the normality test, a general linear model was applied.

$\mathrm{N}$ and $\mathrm{P}$ exports were related to possible explanatory variables, in particular, rainfall amount and intensity, overland flow volumes and

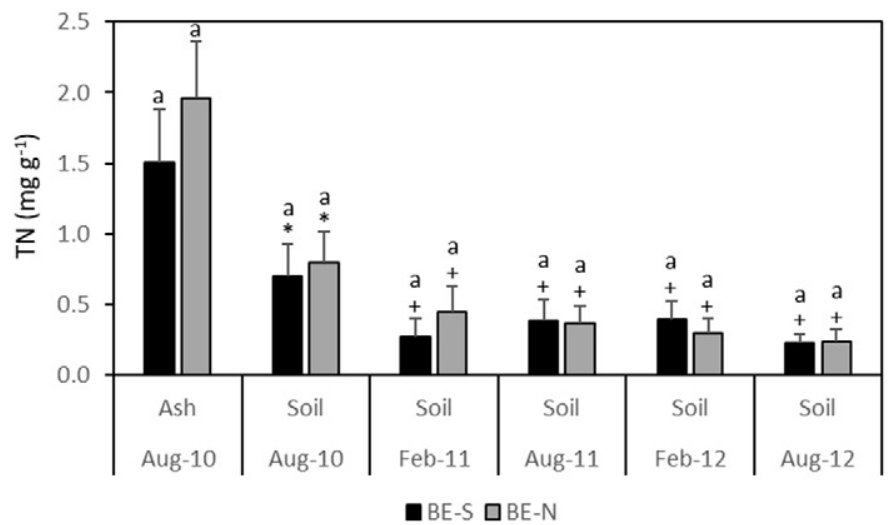

sediment losses. These relationships were assessed using the Spearman's rank correlation coefficient, since most data lacked a normal distribution.

All statistical tests were carried out with the SigmaPlot 14.0 software, using a significance level of 0.05 .

\section{Results and discussion}

\subsection{Nitrogen and phosphorus contents in ash and topsoil}

The average values of TN and $\mathrm{P}_{\mathrm{av}}$ contents in the ash layer and the upper $2 \mathrm{~cm}$ of the topsoil at the two study sites are shown in Fig. 5 .

No significant differences in TN $(t=-1.933 ; p=0.085$; Fig. 5$)$ and $\mathrm{P}_{\mathrm{av}}(t=-0.212 ; p=0.837 ;$ Fig. 5$)$ contents were observed between the ashes collected at the BE-S and BE-N sites. This was in line with the findings of Ferreira et al. (2016a, 2016b) for two other eucalypt sites burnt at moderate severity within the same study area. Such minor differences in the composition of ash produced by similar fire severities can be explained by the similar pre-fire $\mathrm{N}$ and $\mathrm{P}$ contents in aboveground vegetation and litter in eucalypt stands (Magalhães et al., 2011; Ribeiro et al., 2002).

At both study sites, TN and $\mathrm{P}_{\mathrm{av}}$ contents of ash were, on average, two times higher than topsoil contents immediately after the wildfire (Fig. 5). Similar findings were reported by prior studies in northern Portugal (Marão and Caramulo mountains), for both eucalypt

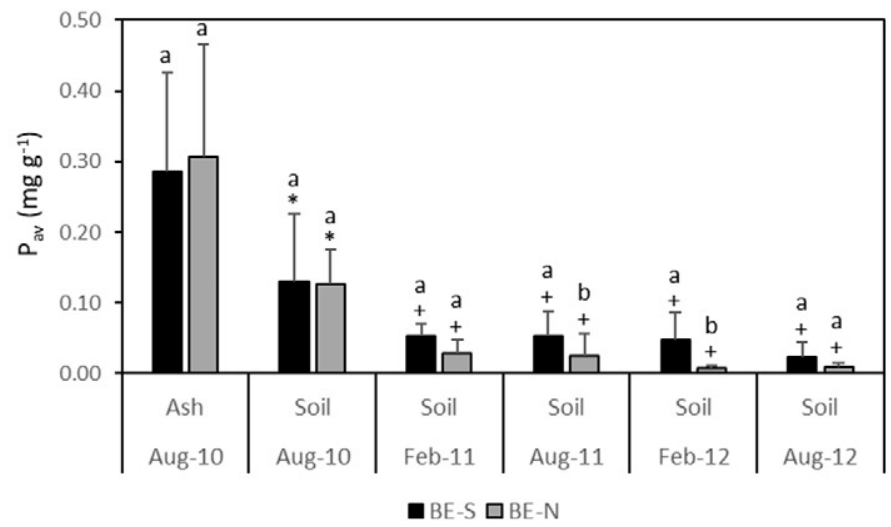

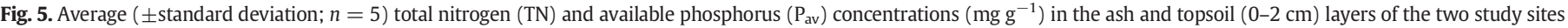

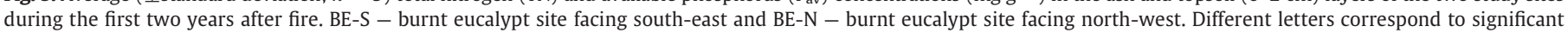
differences $(p<0.05)$ between sites. Different symbols correspond to significant differences $(p<0.05)$ between sampling events. 
Table 2

Summary of the two-way ANOVAs, with interaction terms, for soil total nitrogen (TN) and available phosphorus $\left(\mathrm{P}_{\mathrm{av}}\right)$ contents at the two study sites during the first two years after fire. $\mathrm{df}$ - degrees of freedom, MS - mean square variation, F - F statistic, $p$ - probability value.

\begin{tabular}{llllrr}
\hline Variable & Source of variation & df & MS & \multicolumn{1}{l}{ F } & \multicolumn{1}{l}{$p$} \\
\hline TN & Time & 4 & 0.381 & 16.180 & $<0.001$ \\
& Slope aspect & 1 & 0.013 & 0.550 & 0.463 \\
& Time x slope aspect & 4 & 0.026 & 1.100 & 0.373 \\
$\mathrm{P}_{\mathrm{av}}$ & Time & 4 & 7.119 & 10.568 & $<0.001$ \\
& Slope aspect & 1 & 6.779 & 10.063 & 0.003 \\
& Time x slope aspect & 4 & 1.155 & 1.714 & 0.166 \\
\hline
\end{tabular}

(Thomas et al., 1999, 2000a, 2000b) and pine stands (Costa et al., 2014; Thomas et al., 1999, 2000a, 2000b). This contrast between the ash and topsoil layer could reflect the fast mineralization of organic matter during the combustion of aboveground vegetation and litter (Caon et al., 2014; Kutiel and Inbar, 1993; Santín et al., 2018). The present results differed, however, from those of Ferreira et al. (2016a) who reported higher $\mathrm{P}_{\mathrm{av}}$ contents in the topsoil than in the ash layer of a burnt eucalypt plantation on schist in the same study area. Possibly, soil heating had been stronger at the eucalypt stand of Ferreira et al. (2016a) than at the present stands, as stronger soil heating could explain the lower soil organic matter (SOM) content at their stand immediately after the fire ( $22 \%$ vs. 28 and $32 \%$, at BE-S and BE-N, respectively), and SOM is known to strongly influence $\mathrm{P}$ adsorption processes (Otero et al., 2015). Lower SOM values might have limited the P adsorption capacity of the soils at their stand, in turn, increasing $\mathrm{P}_{\mathrm{av}}$ concentrations to a point that soil values were higher than ash values. Alternatively, differences in the mineral fraction of the soil between the two stands, in particular of iron ( $\mathrm{Fe})$, aluminum ( $\mathrm{Al}$ ) and manganese $(\mathrm{Mn})$ contents, could have also accounted for these results since the formation of oxyhydroxides of these elements has been reported to influence the $\mathrm{P}$ sorption capacity of soils (Otero et al., 2015).

Topsoil TN contents did not differ significantly between the two study sites ( $p=0.463$; Table 2 ), in agreement with the results for the ash layer. By contrast, topsoil $\mathrm{P}_{\mathrm{av}}$ contents were, on overall, significantly lower ( $p=0.003$; Table 2 ) at the BE-N site than at the BE-S site. This site-wise difference in $\mathrm{P}_{\mathrm{av}}$ contents was only significant at the third and fourth sampling occasions, i.e. 12 and 18 months after the fire, but was noticeable at all occasions except immediately after the fire (Fig. 5). A possible explanation for these findings could be the higher $\mathrm{P}$ losses by overland flow at the BE-N site, as detailed in the next section. In turn, the comparable topsoil $\mathrm{P}_{\mathrm{av}}$ as well as TN contents at both sites immediately after the fire could be attributed, besides to the comparable fire severity, to the similar $\mathrm{N}$ and $\mathrm{P}$ contents in aboveground vegetation, litter and topsoil layers that have been reported for eucalypt stands in Portugal (Magalhães et al., 2011; Ribeiro et al., 2002).

Time-since-fire played a significant overall role in both TN $\left(p<0.001\right.$; Table 2; Fig. 5) and $\mathrm{P}_{\mathrm{av}}(p<0.001$; Table 2; Fig. 5) topsoil contents. The most obvious pattern was the decrease in $\mathrm{N}$ and $\mathrm{P}$ contents between the first and second sampling occasion, which corresponded to significant differences at both study sites. This drop was most likely due to the elevated $\mathrm{N}$ and $\mathrm{P}$ losses by runoff during the first post-fire rainfall events as reported by several authors (Caon et al., 2014; Cerdà

\section{Table 4}

Summary of the repeated measures two-way ANOVA, with interaction terms, for overland flow amounts, and sediment, nitrate $\left(\mathrm{NO}_{3}-\mathrm{N}\right)$, total nitrogen $(\mathrm{TN})$, orthophosphate $\left(\mathrm{PO}_{4}{ }^{-}\right.$ $\mathrm{P}$ ) and total phosphorus (TP) losses at the two study sites during the first two years after fire. $\mathrm{df}$ - degrees of freedom, MS - mean square variation, F - F statistic, $p$ - probability value.

\begin{tabular}{llrrrr}
\hline Variable & Source of variation & df & \multicolumn{1}{c}{ MS } & \multicolumn{1}{c}{ F } \\
\hline Overland flow & Plot & 3 & 712.216 & 0.365 & 0.734 \\
& Time & 63 & 2398.751 & 30.873 & $<0.001$ \\
& Slope aspect & 1 & 1730.845 & 0.866 & 0.450 \\
\multirow{3}{*}{ Sediment } & Time x slope aspect & 63 & 132.746 & 1.084 & 0.734 \\
& Plot & 3 & 16.103 & 0.066 & 0.938 \\
& Time & 61 & 901.042 & 36.882 & $<0.001$ \\
& Slope aspect & 1 & 2731.664 & 11.032 & 0.080 \\
$\mathrm{NO}_{3}$-N & Time x slope aspect & 61 & 766.985 & 27.610 & $<0.001$ \\
& Plot & 3 & 17.584 & 0.226 & 0.816 \\
& Time & 41 & 32.480 & 3.152 & $<0.001$ \\
& Slope aspect & 1 & 150.413 & 1.931 & 0.299 \\
$\mathrm{TN}$ & Time x slope aspect & 41 & 15.377 & 1.491 & 0.063 \\
& Plot & 3 & 278.614 & 0.036 & 0.965 \\
& Time & 48 & 7250.56 & 13.577 & $<0.001$ \\
& Slope aspect & 1 & $32,027.420$ & 3.898 & 0.187 \\
$\mathrm{PO}_{4}$-P & Time x slope aspect & 48 & 2190.025 & 2.038 & 0.002 \\
& Plot & 3 & 751.304 & 0.906 & 0.526 \\
& Time & 40 & 307.766 & 2.432 & $<0.001$ \\
& Slope aspect & 1 & 1889.14 & 2.266 & 0.271 \\
& Time x slope aspect & 40 & 263.241 & 2.017 & 0.004 \\
$\mathrm{TP}$ & Plot & 3 & 1882.367 & 0.619 & 0.629 \\
& Time & 47 & 1705.491 & 5.670 & $<0.001$ \\
& Slope aspect & 1 & $10,370.76$ & 3.119 & 0.219 \\
& Time x slope aspect & 47 & 703.116 & 1.202 & 0.223 \\
\hline
\end{tabular}

and Doerr, 2008; Certini, 2005; Ferreira et al., 2016a, 2016b; Khanna et al., 1994; Knoepp et al., 2005; Pausas et al., 2008; Shakesby, 2011; Thomas et al., 1999). After this initial drop, there were no pronounced changes or clear temporal trends in topsoil contents of either TN or $\mathrm{P}_{\mathrm{av}}$, except that the lowest values were observed at the end of the study period. These findings could be explained by the development of a protective soil cover, mainly constituted by vegetation and litter in the case of the BE-N site but also by stones at the BE-S site (Fig. 3), which most likely limited overland flow generation and the associated soil (fertility) losses (Shakesby, 2011).

\subsection{Nitrogen and phosphorus exports by overland flow}

Annual rainfall during the first two years after the fire were respectively $15 \%$ and $33 \%$ lower than the long-term average of $1655 \mathrm{~mm}$ at the nearby rainfall station (cf. Section 2.1). This total of $2508 \mathrm{~mm}$ of rain generated, on average, $783 \mathrm{~mm}$ and $987 \mathrm{~mm}$ of overland flow, at the BE-S and BE-N sites, respectively (Table 3). Although this difference in total overland flow was noticeable $(+26 \%)$, it was not statistically significant (Table 4), reflecting the elevated variability between the four plots at each site (CVs of $36 \%$ and $31 \%$, respectively at the BE-S and $\mathrm{BE}-\mathrm{N}$ sites). The between-site differences in cumulative sediment, TN and TP losses were more pronounced, as average values were $3.3 \times$, $1.9 \times$ and $4.8 \times$ higher at the BE-N than BE-S site, respectively (Table 3), however no significant differences were found between sites (Table 4). In the present study, the export of dissolved $\mathrm{N}$ and $\mathrm{P}$ as $\mathrm{NO}_{3}-\mathrm{N}$ and $\mathrm{PO}_{4}-\mathrm{P}$ could only be determined until April 2012 but the

Table 3

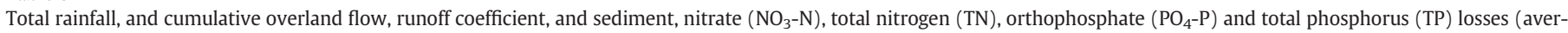

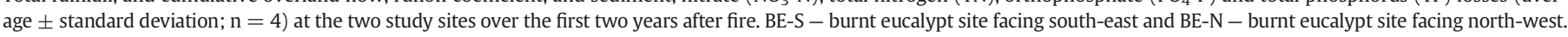

\begin{tabular}{|c|c|c|c|c|c|c|c|c|}
\hline \multirow[t]{2}{*}{ Site } & Rainfall & Overland flow & Runoff coefficient & Sediment losses & $\mathrm{NO}_{3}-\mathrm{N}$ exports & TN exports & $\mathrm{PO}_{4}$-P exports & TP exports \\
\hline & $(\mathrm{mm})$ & $(\mathrm{mm})$ & $(\%)$ & $\left(\mathrm{g} \mathrm{m}^{-2}\right)$ & $\left(\mathrm{g} \mathrm{m}^{-2}\right)^{\mathrm{a}}$ & $\left(\mathrm{g} \mathrm{m}^{-2}\right)^{\mathrm{b}}$ & $\left(\mathrm{g} \mathrm{m}^{-2}\right)^{\mathrm{a}}$ & $\left(\mathrm{g} \mathrm{m}^{-2}\right)^{\mathrm{b}}$ \\
\hline BE-S & 2508 & $783 \pm 283$ & $31 \pm 11$ & $114 \pm 62$ & $0.04 \pm 0.02$ & $1.04 \pm 0.44$ & $0.02 \pm 0.01$ & $0.18 \pm 0.90$ \\
\hline BE-N & & $987 \pm 312$ & $39 \pm 12$ & $376 \pm 138$ & $0.10 \pm 0.06$ & $1.98 \pm 0.30$ & $0.25 \pm 0.15$ & $0.87 \pm 0.58$ \\
\hline
\end{tabular}

\footnotetext{
a $\mathrm{NO}_{3}-\mathrm{N}$ and $\mathrm{PO}_{4}$-P exports were measured between August 2010 and April 2012.
}

b TN and TP exports were measured between August 2010 and August 2012. 
total values accounted for $<6 \%$ and $30 \%$, of the respective TN and TP exports. Also, Lane et al. (2008) and Smith et al. (2011) found that total N and $P$ exports from burnt eucalypt forests in South East Australia were predominantly in particulate form, accounting for $68 \%$ and $86 \%$, respectively, of the overall exports. These findings confirm that disregarding the particulate fraction may lead to an underestimation of wildfire impacts on terrestrial and aquatic ecosystems.

The present finding of a stronger runoff response and greater soil and nutrient losses at the north than south slope contrasted with what has been commonly reported for the Mediterranean basin, both in unburnt and burnt areas (Cerdà et al., 1995; Wittenberg and Inbar, 2009; Wittenberg et al., 2014). The typically stronger response of south compared to north slopes in burnt areas has been attributed to a slower post-fire vegetation recovery, reflecting more pronounced drought and higher solar radiation (Cerdà et al., 1995; GabarrónGaleote et al., 2013; Kutiel and Lavee, 1999; Wittenberg and Inbar, 2009; Wittenberg et al., 2014). As shown in Fig. 3, also in this study vegetation recovery was slower at the south than north slope but vegetation cover was low throughout the study period $(<20 \%)$ and unlikely to have played a relevant role. Alternatively, the higher stone cover along the south slope could have accounted for its lower overland flow amounts and soil (fertility) losses, since stones are known to not only affect hydrological processes, e.g. rainfall interception, infiltration, percolation and runoff generation (Urbanek and Shakesby, 2009), but also to limit the extent and/or continuity of water repellent soils (Urbanek and Shakesby, 2009) and the availability of sediments for transport (Shakesby, 2011).

The runoff-erosion differences observed here were probably linked to pre-fire land management and, in particular, the logging operation that had taken place at the BE-N site shortly before the fire. The logging machinery is likely to have modified soil properties and disturbed vegetation, thereby affecting both pre- and post-fire hydrological and erosion processes (Malvar et al., 2017; Vieira et al., 2016). A decrease in above-ground vegetation cover by logging will reduce interception and, thereby, increase effective rainfall volume, intensity as well as erosivity (Beasley and Granillo, 1985). In addition, soil compaction by heavy machinery will decrease infiltration capacity and, at the same time, increase soil erodibility (Carr and Loague, 2012; Huang et al., 1996). Differences in overland flow, sediment and nutrient losses between slopes were evident over time (Figs. 6 and 7).

Time-since-fire had a significant overall effect on sediment and nutrient mobilization by runoff, while slope position did not (Table 4) similarly to what has been reported by other authors for this region (Hosseini et al., 2017; Malvar et al., 2017). At both study sites, the
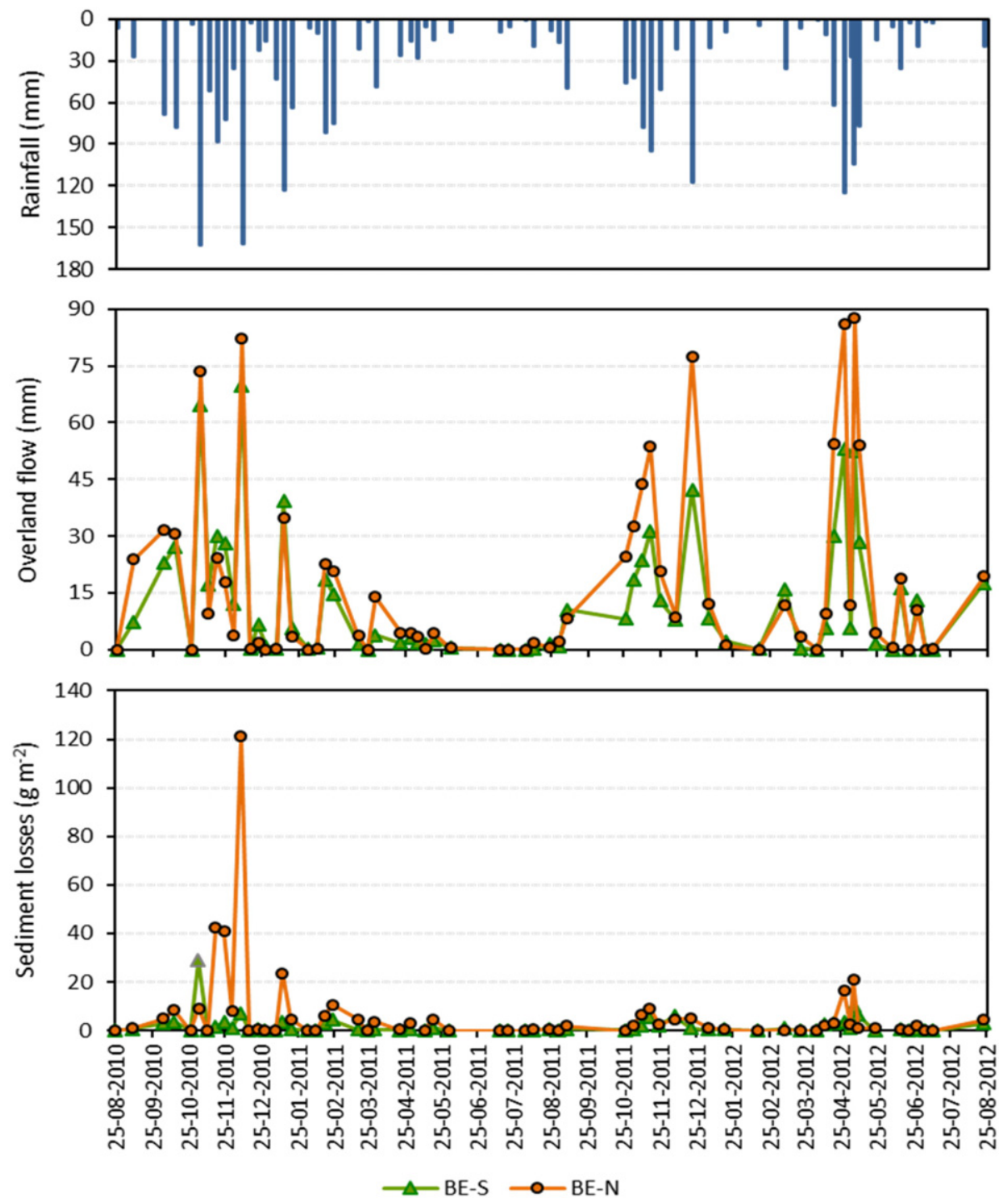

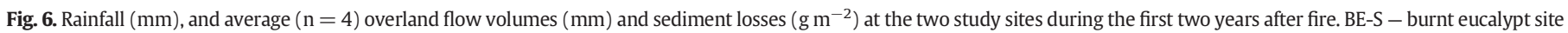
facing south-east and BE-N - burnt eucalypt site facing north-west. 

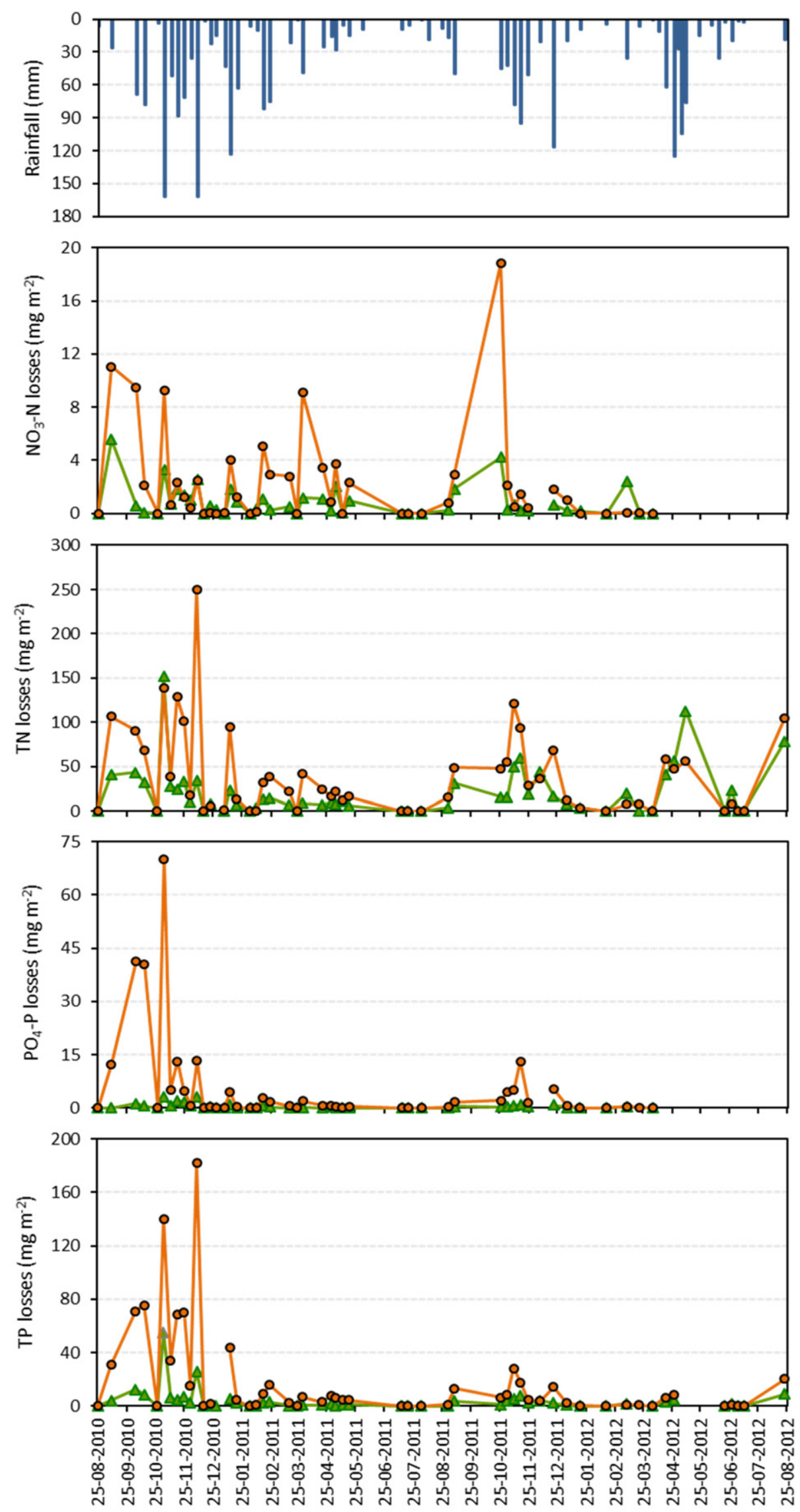

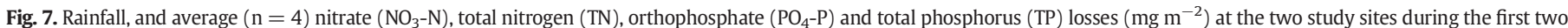
years after fire. BE-S - burnt eucalypt site facing south-east and BE-N - burnt eucalypt site facing north-west. 
greatest $\mathrm{N}$ and $\mathrm{P}$ losses occurred during the first 4 months after fire (Fig. 7), i.e. during the early stages of the "window-of-disturbance" (Burke et al., 2005; Lane et al., 2008; Shakesby and Doerr, 2006). This was likely due to the wash-off of the nutrient-enriched ash layer (Caon et al., 2014; Khanna et al., 1994; Knoepp et al., 2005; Shakesby, 2011; Thomas et al., 1999), combined with a lack of protective soil cover (Bodí et al., 2014; Ferreira et al., 2005; Thomas et al., 1999). In the case of the south slope, such a wash-off of the ash layer was also suggested by a strong decrease in the ash cover between August 2010 and January 2011 (Fig. 3). The peaks in N and P exports during this initial period were typically associated with peaks in rainfall (Fig. 7). At both study sites, the exports of $\mathrm{TN}$, TP and $\mathrm{PO}_{4}$-P were significantly related not only with rainfall volumes and maximum intensities but also with overland flow amounts and sediment losses, with no obvious differences in the strengths of these correlations (Table 5). Even so, important peaks in rainfall as well as overland flow during the second post-fire year did not produce marked exports of especially TP and $\mathrm{PO}_{4}-\mathrm{P}$, suggesting a faster exhaustion of $\mathrm{P}$ than $\mathrm{N}$ stocks in the ash and topsoil layers. The export of $\mathrm{NO}_{3}-\mathrm{N}$ at both study sites was also significantly correlated with rainfall and overland flow volumes, but the correlations were not very strong (Table 5 ). $\mathrm{NO}_{3}-\mathrm{N}$ further stood out for the fact that the highest peak in exports occurred during the second year after fire (October 2011), associated to a relatively low rainfall $(45 \mathrm{~mm}$ and $12 \mathrm{~mm} \mathrm{~h}^{-1}$ ) as well as runoff events $(25 \mathrm{~mm})$. A possible explanation could be related with a boost in soil $\mathrm{N}$ mineralization and nitrification processes (Lane et al., 2008) due to the first rainfall events after the dry summer season, which were possibly enhanced by the continued presence of an elevated ash cover.

A comparison of the present results with the - relatively few - plotscale studies of post-fire $\mathrm{N}$ and $\mathrm{P}$ exports in Mediterranean-type ecosystems, revealed that the current figures were within the expected ranges (Ferreira et al., 2005; Hosseini et al., 2017; Thomas et al., 2000b). Using similar micro-plots, Hosseini et al. (2017) found cumulative TN and TP exports over the first two years after fire to amount to 0.70 and $0.66 \mathrm{~g} \mathrm{~m}^{-2}$, respectively, as opposed to the 1.04-1.98 and $0.18-0.87 \mathrm{~g} \mathrm{~m}^{-2}$ of this study. Worth noting is that these results of Hosseini et al. (2017) concerned a different forest type, i.e. Maritime pine plantations. Hosseini et al. (2017) also reported markedly higher values (TN: $2.78 \mathrm{~g} \mathrm{~m}^{-2}$; TP: $1.51 \mathrm{~g} \mathrm{~m}^{-2}$ ) but those concerned Maritime Pine plantations that had suffered recurrent fires (i.e. 4 time burned as opposed to once burned in 34 years) and, linked to that, lacked spontaneous needle cast due to complete consumption of the tree crowns. The temporal patterns in nutrient exports reported by Hosseini et al. (2017), however, contrasted with the present ones, in that their exports were clearly higher during the second year following the wildfire. The authors attributed their somewhat anomalous results to the reduced rainfall during their first post-fire year. Likewise, Vieira et al. (2016) found that the runoff-erosion response of micro-plots during the first four years depended more on rainfall regime than time-since-fire per se.

\section{Table 5}

Spearman rank correlation coefficients of post-fire nitrate $\left(\mathrm{NO}_{3}-\mathrm{N}\right)$, total nitrogen $(\mathrm{TN})$, orthophosphate $\left(\mathrm{PO}_{4}-\mathrm{P}\right)$ and total phosphorus ( $\mathrm{PO}_{4}-\mathrm{P}$ and $\left.\mathrm{TP}\right)$ losses with rainfall amounts, maximum rainfall intensities during $30 \mathrm{~min}\left(\mathrm{I}_{30}\right)$, overland flow volumes and sediment losses. BE-S - burnt eucalypt site facing south-east and BE-N - burnt eucalypt site facing north-west. Significant values $(p \leq 0.05)$ are presented in bold.

\begin{tabular}{llllll}
\hline \multirow{2}{*}{ Site } & & \multicolumn{4}{l}{ Nutrient losses $\left(\mathrm{mg} \mathrm{m}^{-2}\right)$} \\
\cline { 3 - 6 } & Variable & $\mathrm{NO}_{3}-\mathrm{N}$ & $\mathrm{TN}$ & $\mathrm{PO}_{4}-\mathrm{P}$ & $\mathrm{TP}$ \\
\hline \multirow{2}{*}{$\mathrm{BE}-\mathrm{S}$} & Rainfall $(\mathrm{mm})$ & $\mathbf{0 . 4 7}$ & $\mathbf{0 . 8 2}$ & $\mathbf{0 . 7 3}$ & $\mathbf{0 . 8 5}$ \\
& $\mathrm{I} 30\left(\mathrm{~mm} \mathrm{~h}^{-1}\right)$ & 0.34 & $\mathbf{0 . 8 4}$ & $\mathbf{0 . 5 9}$ & $\mathbf{0 . 8 5}$ \\
& Overland flow $(\mathrm{mm})$ & $\mathbf{0 . 5 0}$ & $\mathbf{0 . 9 0}$ & $\mathbf{0 . 7 7}$ & $\mathbf{0 . 9 1}$ \\
& Sediment losses $\left(\mathrm{g} \mathrm{m}^{-2}\right)$ & 0.39 & $\mathbf{0 . 8 6}$ & $\mathbf{0 . 6 7}$ & $\mathbf{0 . 8 5}$ \\
BE-N & Rainfall $\left(\mathrm{mm}^{-1}\right)$ & $\mathbf{0 . 4 8}$ & $\mathbf{0 . 8 6}$ & $\mathbf{0 . 7 7}$ & $\mathbf{0 . 8 7}$ \\
& I30 $\left(\mathrm{mm} \mathrm{h}^{-1}\right)$ & 0.38 & $\mathbf{0 . 8 7}$ & $\mathbf{0 . 6 4}$ & $\mathbf{0 . 8 6}$ \\
& Overland flow $\left(\mathrm{mm}^{2}\right.$ & $\mathbf{0 . 5 0}$ & $\mathbf{0 . 9 2}$ & $\mathbf{0 . 7 7}$ & $\mathbf{0 . 8 6}$ \\
& Sediment losses $\left(\mathrm{g} \mathrm{m}^{-2}\right)$ & 0.38 & $\mathbf{0 . 8 1}$ & $\mathbf{0 . 6 8}$ & $\mathbf{0 . 8 3}$
\end{tabular}

The present results on dissolved nutrient exports also agreed well with those of previous studies carried out in the study region (foothills of the Caramulo Mountains). In the case of $\mathrm{NO}_{3}-\mathrm{N}$, the export from an eucalypt forest over the first post-fire year ranged from $0.04-0.11 \mathrm{~g} \mathrm{~m}^{-2}$ (Thomas et al., 2000b), i.e. similar to the present range of $0.04-0.10 \mathrm{~g} \mathrm{~m}^{-2}$, in spite of the larger plot size $\left(16 \mathrm{~m}^{2}\right)$ of Thomas et al. (2000b). The authors still reported comparable values of $\mathrm{NO}_{3}-\mathrm{N}$ exports over the first post-fire year for Maritime pine forest (0.04-0.11 $\mathrm{g} \mathrm{m}^{-2}$ ) and so did Ferreira et al. (2005: $\left.0.05 \mathrm{~g} \mathrm{~m}^{-2}\right)$. The concomitant $\mathrm{PO}_{4}-\mathrm{P}$ exports reported by Thomas et al. (2000b), however, involved narrower and lower ranges than those observed in this study $\left(0.02-025 \mathrm{~g} \mathrm{~m}^{-2}\right)$, not only in the case of their eucalypt plots $\left(0.04-0.06 \mathrm{~g} \mathrm{~m}^{-2}\right)$ but especially in the case of their pine plots $\left(0.001-0.008 \mathrm{~g} \mathrm{~m}^{-2}\right)$. In the same burnt area as studied here, Ferreira et al. (2016a, 2016b) also found greater TN and TP exports for eucalypt than pine plots but this contrast between the two forest types was consistent for $\mathrm{N}$ and $\mathrm{P}$ and, for dissolved and total exports.

Overall Nlosses by overland flow over the 2-year study period (Table 3 ) represented $10 \%$ and $20 \%$ of the differences in topsoil $\mathrm{N}$ stocks between the $1 \mathrm{st}$ and 24 th month after the fire, at the BE-S $\left(10.9 \mathrm{~g} \mathrm{~m}^{-2}\right)$ and $\mathrm{BE}-\mathrm{N}$ site $\left(9.8 \mathrm{~g} \mathrm{~m}^{-2}\right)$, respectively. These values were even lower in the case of dissolved/available $\mathrm{P}$, as the $\mathrm{PO}_{4}$-P losses represented only $1 \%$ and $13 \%$ of the topsoil available P stocks at the BE-S $\left(2.5 \mathrm{~g} \mathrm{~m}^{-2}\right)$ and BE$\mathrm{N}$ site $\left(2.0 \mathrm{~g} \mathrm{~m}^{-2}\right)$, respectively. These results were expectable since $\mathrm{PO}_{4}$-P has been reported to be mainly transported adsorbed to eroded sediments rather than in its dissolved form (Thomas et al., 2000b). Although this decrease in soil $\mathrm{N}$ and $\mathrm{P}$ stocks cannot be exclusively attributed to post-fire water erosion, as plant and soil microbial recovery, for example, can also contribute to such a decline (Goodridge et al., 2018), these results support the idea that moderate severity fires could enhance the risk of soil fertility loss in Mediterranean forest areas (Caon et al., 2014).

\subsection{Nitrogen and phosphorus concentrations in overland flow and implica- tions for surface water quality}

Dissolved and total $\mathrm{N}\left(\mathrm{NO}_{3}-\mathrm{N}\right.$ and $\left.\mathrm{TN}\right)$ and $\mathrm{P}\left(\mathrm{PO}_{4}-\mathrm{P}\right.$ and $\left.\mathrm{TP}\right)$ concentrations in overland flow are presented in Fig. 8. Peaks in $\mathrm{N}$ and $\mathrm{P}$ concentrations were considerably higher at the BE-N site than at the BE-S site, in line with what was observed for $\mathrm{N}$ and $\mathrm{P}$ exports (Fig. 7). Unlike export peaks, however, peaks in $\mathrm{N}$ and $\mathrm{P}$ concentrations, were often unrelated to the major rainfall-runoff events, reflecting the complexity of biogeochemical processes in burnt areas (Caon et al., 2014; Murphy et al., 2006). Noteworthy, the temporal patterns in nutrient concentrations varied markedly between the two elements (Fig. 8). In the case of dissolved as well as total P concentrations, the highest peaks coincided with the first significant post-fire rainfall events, likely due to the detachment and transport of the P-enriched easily-erodible ash layer (Ferreira et al., 2005; Lane et al., 2008; Thomas et al., 1999; Santín et al., 2018). By contrast, the major peaks in dissolved and total $\mathrm{N}$ concentrations, occurred all over the monitoring period, suggesting that the availability of $\mathrm{N}$ forms for export may be dependent on an interplay of biogeochemical processes such as $\mathrm{N}$ mineralization and nitrification (Lane et al., 2008).

The comparison of the observed TN and TP levels in post-fire overland flow with the Portuguese quality standards for multi-purpose surface waters (SNIRH, 2019: TN $\approx 52 \mathrm{mg} \mathrm{L}^{-1}$, TP $-0.4 \mathrm{mg} \mathrm{L}^{-1}$ ) suggested that $P$ is more likely to cause water quality problems than N. Phosphorus concentrations in overland flow exceeded the quality threshold levels at several occasions, especially during the first 4 months after fire, reinforcing the need for timely application of post-fire erosion mitigation measures. This risk of P contamination has also been referred in other studies dealing with other forest types and water quality standards (Blake et al., 2009a, 2009b, 2010; Burd et al., 2018; Burke et al., 2005; Santín et al., 2018; Santos et al., 2015; Silins et al., 2014; Stein et al., 2012). 

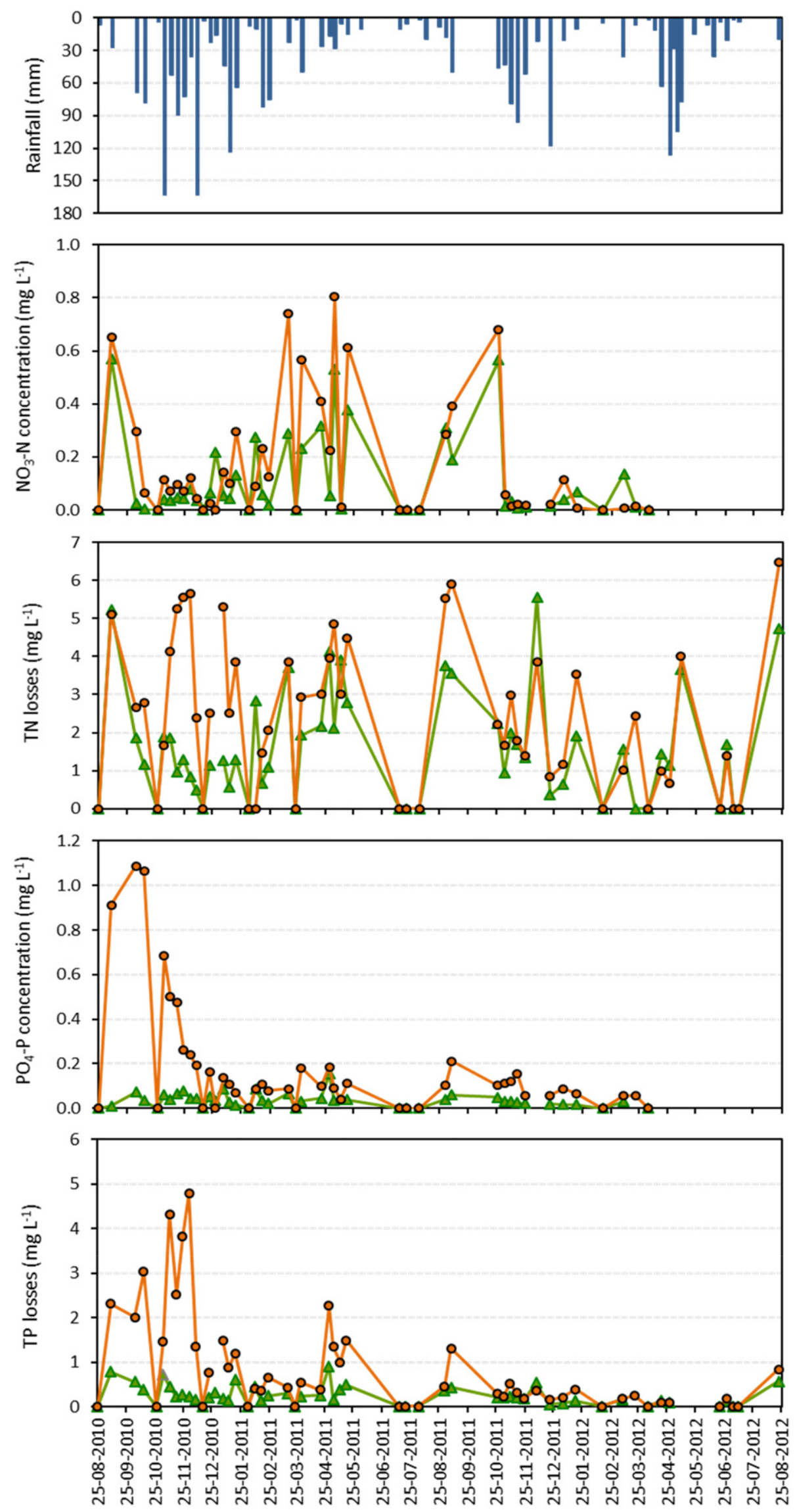


\section{Conclusions}

The present study provides an estimate of the range of $\mathrm{N}$ and $\mathrm{P}$ exports from burnt eucalypt forests in the Mediterranean region, which is crucial for understanding the potential indirect effects of wildfires on soil fertility as well as on the water quality of downstream aquatic ecosystems.

The obtained results suggested that the role of pre-fire land management can obscure that of slope aspect since post-fire nutrient exports were higher at the north-facing slope than at the south-facing slope, unlike what was expected from prior field studies in the Mediterranean. This discrepancy with prior findings could be explained, at least in part, by the logging operation that had taken place on the north-facing slope shortly before the fire, therefore suggesting that recently logged eucalypt plantations should be considered a priority when planning post-fire erosion mitigation treatments. Nevertheless, more studies are needed to further evaluate the effect of pre-fire management operations on post-fire nutrient exports, ideally comparing slope parts or slopes with similar characteristics except for the pre-fire management operations.

Post-fire $\mathrm{N}$ and $\mathrm{P}$ exports revealed to be strongly associated to the first post-fire rainfall events, implying that post-fire risks of on-site soil fertility losses and off-site eutrophication of water bodies require rapid intervention. At the same time, however, $\mathrm{N}$ and $\mathrm{P}$ exports also peaked after this initial 4-month period, so that wildfire impacts on forest and aquatic ecosystems need to be assessed over periods of at least 2 and ideally $4-5$ years, also depending on fire severity and forest ecosystem resilience.

Although plot-scale studies as the present one provide important insights into the export of nutrients after wildfires, there is still a strong and urgent need for similar studies at the catchment scale. Despite being very challenging, because of the difficulties in installing and maintaining equipment in the field as well as the expense involved, such studies are indispensable to validate model predictions that, directly or indirectly, scale up plot-scale results.

\section{Declaration of competing interest}

No conflict of interests.

\section{Acknowledgements}

This work was performed within the scope of the FIRECNUTS project (PTDC/AGR-CFL/104559/2008), which was funded by FEDER, through COMPETE (Programa Operacional Factores de Competitividade; POFC) and by national funds (OE), through FCT/MCTES. The work was also supported by the FIREMIX project (PTDC/BIA-ECO/29601/2017) funded by FEDER, through COMPETE2020 - Programa Operacional Competitividade e Internacionalização (POCI), and by national funds (OE), through FCT/MCTES. The authors would further like to acknowledge the financial support of CESAM (UID/AMB/50017/2019) by FCT/ MCTES, through national funds. Dalila Serpa was funded by national funds (OE) through FCT, I.P., in the scope of the framework contract foreseen in the numbers 4,5 and 6 of the article 23, of the Decree-Law $57 / 2016$, of August 29, changed by Law 57/2017, of July 19 . Thanks are also due to FCT for the Post-Doc grant of Dalila Serpa (SFRH/BPD/ 92650/2013), the IF research grant of Jacob Keizer (IF/01465/2015) and the PhD. grant of Raquel Vasconcelos Ferreira (SFRH/BD/45778/ 2008). A special thanks is due to various members of the ESP team (http://espteam.web.ua.pt/) for their help with field work, to Óscar González-Pelayo for his assistance with soil profile descriptions and to Diana Patoilo, head of the laboratory of the Department of Environment and Planning of the University of Aveiro, for her help with the laboratory analyses. The authors also gratefully acknowledge the editor and two anonymous reviewers for their helpful comments and suggestions, which substantially improved the manuscript.

\section{References}

Abraham, J., Dowling, K., Singarayer, F., 2017. Risk of post-fire metal mobilization into surface water resources: a review. Sci. Total Environ. 599-600, 1740-1755. https://doi. org/10.1016/j.scitotenv.2017.05.096.

APHA (American Public Health Association), 1998. Standard Methods for the Examination of Water and Wastewater. APHA, Washington D.C.

Badía, D., Martí, C., Aguirre, A.J., Aznar, J.M., González-Pérez, J.A., De la Rosa, J.M., León, J., Ibarra, P., Echeverría, T., 2014. Wildfire effects on nutrients and organic carbon of a Rendzic Phaeozem in NE Spain: changes at cm-scale topsoil. Catena 113, 267-275. https://doi.org/10.1016/j.catena.2013.08.002.

Beasley, R.S., Granillo, A.B., 1985. Soil protection by natural vegetation on clear-cut forest land in Arkansas. J. Soil Water Conserv. 40 (4), 379-382.

Bladon, K.D., Emelko, M.D., Silins, U., Stone, M., 2014. Wildfire and the future of water supply. Environ. Sci. Technol. 48, 8936-8943. https://doi.org/10.1021/es500130g.

Blake, W.H., Wallbrink, P.J., Dropp, I.G., Doerr, S.H., Humphreys, G.S., Shakesby, R.A., Tomkins, K.M., 2009a. Sediment aggregation and water quality in wildfire affected river basins. Mar. Freshw. Res. 60, 653-659. https://doi.org/10.1071/MF08068.

Blake, W.H., Wallbrink, P.J., Wilkinson, S.N., Humphreys, G.S., Doerr, S.H., Shakesby, R.A., Tomkins, K.M., 2009b. Deriving hillslope sediment budgets in wildfire-affected forests using fallout radionuclide tracers. Geomorphology 104, 105-116. https://doi. org/10.1016/j.geomorph.2008.08.004

Blake, W.H., Theocharopoulos, S.P., Skoulikidis, N., Clark, P., Tountas, P., Hartley, R., Amaxidis, Y., 2010. Wildfire impacts on hillslope sediment and phosphorus yields. J. Soils Sediments 10, 671-682. https://doi.org/10.1007/s11368-010-0201-y.

Bodí, M.B., Martin, D.A., Balfour, V.N., Santín, C., Doerr, S.H., Pereira, P., Cerdà, A., MataixSolera, J., 2014. Wildland fire ash: production, composition and eco-hydrogeomorphic effects. Earth Sci. Rev. 130, 103-127.

Botelho da Costa, J., 2004. Caracterização e constituição do solo. 7th ed. Fundação Calouste Gulbenkian, Lisbon.

Bray, R.H., Kurtz, L.T., 1945. Determination of total, organic and available forms of phosphorus in soils. Soil Sci. 59, 39-45. https://doi.org/10.1097/00010694-19450100000006.

Bremner, J.M., 1979. Total Nitrogen. In: Black, A., Evans, D.D., White, J.L., Ensmingert, L.E., Clark, F.E. (Eds.), Methods of Soil Analyses - Chemical and Microbiological Properties. Part 2. American Society of Agronomy, Madison, Wiscosin, pp. 1149-1176.

Burd, K., Tank, S.E., Dion, N., Quinton, W.L., Spence, C., Tanentzap, A.J., Olefeldt, D., 2018. Seasonal shifts in export of DOC and nutrients from burned and unburned peatland-rich catchments, Northwest Territories, Canada. Hydrol. Earth Syst. Sci. 22, 4455-4472. https://doi.org/10.5194/hess-22-4455-2018.

Burke, J.M., Prepas, E.E., Pinder, S., 2005. Runoff and phosphorus export patterns in large forested watersheds on the western Canadian Boreal Plain before and for 4 years after wildfire. J. Environ. Eng. Sci. 4, 319-325. https://doi.org/10.1139/S04-072.

Cancelo-González, J., Rial-Rivas, M.E., Diaz-Fierros, F., 2013. Effects of fire on cation content in water: a laboratory simulation study. Int. J. Wildland Fire 22, 667-680. https://doi.org/10.1071/WF12178.

Caon, L., Vallejo, V.R., Coen, R.J., Geissen, V., 2014. Effects of wildfire on soil nutrients in Mediterranean ecosystems. Earth Sci. Rev. 139, 47-58. https://doi.org/10.1016/j. earscirev.2014.09.001.

Carr, A., Loague, K., 2012. Physics-based simulations of the impacts forest management practices have on hydrological response. In: Standiford, R.B., Weller, T.J., Piirto, D.D., Stuart, J.D. (Eds.), The Coast Redwoods in a Changing California. USDA Forest Service, Santa Cruz, pp. 41-51.

Cerdà, A., 1998. The influence of aspect and vegetation on seasonal changes in erosion under rainfall simulation on a clay soil in Spain. Can. J. Soil Sci. 78, 321-330. https://doi.org/10.4141/S97-060.

Cerdà, A., Doerr, S.H., 2008. The effect of ash and needle cover on surface runoff and erosion in the immediate post-fire period. Catena 74, 256-263. https://doi.org/10.1016/j. catena.2008.03.010.

Cerdà, A. Imeson, A.C. Calvo, A. 1995. Fire and aspect induced differences on the erodibility and hydrology of soils at La Costera, Valencia, southeast Spain. Catena 24, 289-304. https://doi.org/10.1016/0341-8162(95)00031-2.

Certini, G., 2005. Effects of fire on properties of forest soils: a review. Oecologia 143, 1-10. https://doi.org/10.1007/s00442-004-1788-8

Coelho, C.O.A., Ferreira, A.J.D., Boulet, A.K., Keizer, J.J., 2004. Overland flow generation processes, erosion yields and solute loss following different intensity fires. Q. J. Eng. Geol. Hydrogeol. 37, 233-240. https://doi.org/10.1144/1470-9236/03-043.

Costa, M.R., Calvão, A.R., Aranha, J., 2014. Linking wildfire effects on soil and water chemistry of the Marão River watershed, Portugal, and biomass changes detected from Landsat Imagery. Appl. Geochem. 44, 93-102. https://doi.org/10.1016/j. apgeochem.2013.09.009.

DeBano, L.F., Neary, D.G., Folliott, P.F., 1998. Fire's Effects on Ecosystems. John Wiley \& Sons, New York.

Díaz-Fierros, F., Benito, E., Vega, J.A., Castelao, A., Soto, B., Pérez, R., Taboada, T., 1990. Solute loss and soil erosion in burned soil form Galicia (NW Spain). In: Goldammer, J.G., Jenkins, M.J. (Eds.), Fire in Ecosystem Dynamics: Mediterranean and Northern Perspective. SPB Academic Publishing, The Hague, pp. 103-116.

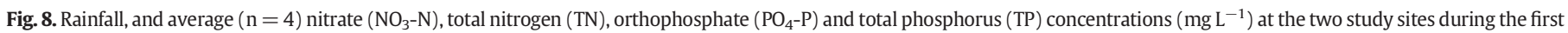
two years after fire. BE-S - burnt eucalypt site facing south-east and BE-N - burnt eucalypt site facing north-west. 
DRA-Centro (Direccão Regional do Ambiente do Centro), 2002. Plano de bacia hidrográfica do Rio Vouga, $1^{\text {a }}$ fase, Análise e diagnóstico da situação de referência. Análise biofísica, Anexos, Lisbon.

DUDF (Direcção de Unidade de Defesa da Floresta), 2011. Relatório Anual de Áreas Ardidas e Ocorrências 2010. Autoridade Florestal Nacional, Lisbon.

Emelko, M.B., Stone, M., Silins, U., Allin, D., Collins, A.L., Williams, C.H.S., Martens, A.M., Bladon, K.D., 2016. Sediment-phosphorus dynamics can shift aquatic ecology and cause downstream legacy effects after wildfire in large river systems. Glob. Chang. Biol. 22, 1168-1184. https://doi.org/10.1111/gcb.13073.

Fernández, C., Vega, J.A., Fontúrbel, M.T., Pérez, J.R., Jiménez, E., Madrigal, J., 2007. Effects of wildfire, salvage logging and slash treatments on soil degradation. Land Degrad. Dev. 18, 591-607. https://doi.org/10.1002/ldr.797.

Fernández, C., Vega, J.A., Fontúrbel, T., 2013. Fuel reduction at a Spanish heathland by prescribed fire and mechanical shredding: effects on seedling emergence. J. Environ. Manag. 129, 621-627. https://doi.org/10.1016/j.jenvman.2013.08.034.

Ferreira, A., 1978. Planaltos e montanhas do norte da Beira - estudo de geomorfologia. Centro de Estudos Geográficos, Lisbon, Portugal.

Ferreira, A.J.D., Coelho, C.O.A., Shakesby, R.A., Walsh, R.P.D., 1997. Sediment and solute yield, in forested ecosystems affected by fire and rip-ploughing techniques - Central Portugal: a plot and catchment analysis approach. Phys. Chem. Earth 22, 309-314. https://doi.org/10.1016/S0079-1946(97)00150-X.

Ferreira, A.J.D., Coelho, C.O.A., Boulet, A.K., Lopes, F.P., 2005. Temporal patterns of solute loss following wildfires in Central Portugal. Int. J. Wildland Fire 14, 401-412. https://doi.org/10.1071/WF05043.

Ferreira, R.V., Serpa, D., Cerqueira, M.A., Keizer, J.J., 2016a. Short-time phosphorus losses by overland flow in burnt pine and eucalypt plantations in north-central Portugal: a study at micro-plot scale. Sci. Total Environ. 551-552, 631-639. https://doi.org/ 10.1016/j.scitotenv.2016.02.036.

Ferreira, R.V., Serpa, D., Machado, A.I., Rodríguez-Blanco, M.L., Santos, L.F., Taboada-Castro, M.T., Cerqueira, M.A., Keizer, J.J., 2016b. Short-term nitrogen losses by overland flow in a recently burnt forest area in north-central Portugal: a study at micro-plot scale. Sci. Total Environ. 572, 1281-1288. https://doi.org/10.1016/j.scitotenv.2015.12.042.

Gabarrón-Galeote, M.A., Ruiz-Sinoga, J.D., Quesada, M.A., 2013. Influence of aspect in soil and vegetation water dynamics in dry Mediterranean conditions: functional adjustment of evergreen and semi-deciduous growth forms. Ecohydrology 6, 241-255. https://doi.org/10.1002/eco.1262.

Goodridge, B.M., Hanan, E.J., Aguilera, R., Wetherley, E.B., Chen, Y.-J., D’Antonio, C.M., Melack, J.M., 2018. Retention of nitrogen following wildfire in a chaparral ecosystem. Ecosystems 21, 1608-1622. https://doi.org/10.1007/s10021-018-0243-3.

Guitián, F., Carballas, T., 1976. Técnicas de análisis de suelos. Pico Sacro, Santiago de Compostela.

Hosseini, M., Geissen, V., González-Pelayo, O., Serpa, D., Machado, A.I., Ritsema, C., Keizer J.J., 2017. Effects of fire occurrence and recurrence on nitrogen and phosphorus losses by overland flow in maritime pine plantations in north-central Portugal. Geoderma 289, 97-106. https://doi.org/10.1016/j.geoderma.2016.11.033.

Huang, J., Lacey, S.T., Ryan, P.J., 1996. Impact of forest harvesting on the hydraulic properties of surface soil. Soil Sci. 161, 79-86. https://doi.org/10.1097/00010694199602000-00001.

IUSS Working Group WRB, 2015. World reference base for soil resources 2014 - update 2015. International soil classification system for naming soils and creating legends for soil maps. World Soil Resources Reports No. 106. FAO, Rome.

Khanna, P.K., Raison, R.J., Falkiner, R.A., 1994. Chemical properties of ash derived from Eucalyptus litter and its effects on forest soils. For. Ecol. Manag. 66, 107-125. https://doi. org/10.1016/0378-1127(94)90151-1.

Knoepp, J.D., DeBano, L.F., Neary, D.G., 2005. Chapter 3: Soil chemistry. In: Neary, D.G., Ryan, K.C., DeBano, L.F. (Eds.), Wildfire in Ecosystems - Effects of Fire on Soil and Water. General Technical Report RMRS-GTR-42. volume 4. United States Department of Agriculture, Ogden, pp. 53-71.

Kutiel, P., Inbar, M., 1993. Fire impacts on soil nutrients and soil-erosion in a Mediterranean pine forest plantation. Catena 20,129-139. https://doi.org/10.1016/0341-8162 (93)90033-L.

Kutiel, P., Lavee, H., 1999. Effect of slope aspect on soil and vegetation properties along an aridity transect. Isr. J. Plant Sci. 47 (3), 169-178. https://doi.org/10.1080/ 07929978.1999.10676770.

Lane, P.N.J., Sheridan, G.J., Noske, P.J., Sherwin, C.B., 2008. Phosphorus and nitrogen exports from SE Australian forests following wildfire. J. Hydrol. 361, 186-198. https:// doi.org/10.1016/j.jhydrol.2008.07.041.

Lasanta, T., Cerdà, A., 2005. Long-term erosional responses after fire in the Central Spanish Pyrenees 2. Solute release. Catena 60, 81-100. https://doi.org/10.1016/j. catena.2004.09.005.

Machado, A.I., Serpa, D., Ferreira, R.V., Rodríguez-Blanco, M.L., Pinto, R., Nunes, M.I. Cerqueira, M.C., Keizer, J.J., 2015. Cation export by overland flow in a recently burnt forest area in north-central Portugal. Sci. Total Environ. 524-525, 201-212.

Magalhães, M.C., Cameira, M.C., Pato, R.L., Santos, F., Bandeira, J., 2011. Residual forest biomass: effects of removal on soil quality. Rev. Ciênc. Agron. Agrár. 34, 205-217.

Malvar, M.C., Prats, S.A., Keizer, J.J., 2016. Runoff and inter-rill erosion affected by wildfire and pre-fire ploughing in eucalypt plantation of north-central Portugal. Land Degrad. Dev. 27, 1314-1318. https://doi.org/10.1002/ldr.2365.

Malvar, M.C., Silva, F.C., Prats, S.A., Vieira, D.C.S., Coelho, C.O.A., Keizer, J.J., 2017. Shortterm effects of post-fire salvage logging on runoff and soil erosion. For. Ecol. Manag. 400, 555-567. https://doi.org/10.1016/j.foreco.2017.06.031.

Mayor, A.G., Valdecantos, A., Vallejo, V.R., Keizer, J.J., Bloem, J., Baeza, J., González-Pelayo, O., Machado, A.I., de Ruiter, P.C., 2016. Fire-induced pine woodland to shrubland transitions in Southern Europe may promote shifts in soil fertility. Sci. Total Environ. 573, 1232-1241. https://doi.org/10.1016/j.scitotenv.2016.03.243.
Moody, J.A., Shakesby, R.A., Robichaud, P.R., Cannon, S.H., Martin, D.A., 2013. Current research issues related to post-wildfire runoff and erosion processes. Earth Sci. Rev. 122, 10-37. https://doi.org/10.1016/j.earscirev.2013.03.004.

Murphy, J.D., Johnson, D.W., Miller, W.W., Walker, R.F., Carroll, E.F., Blank, R.R., 2006 Wildfire effects on soil nutrients and leaching in a Tahoe basin watershed. J. Environ. Qual. 35, 479-489. https://doi.org/10.2134/jeq2005.0144.

Neary, D.G., Klopatek, C.C., DeBano, L.F., Folliott, P.F., 1999. Fire effects on belowground sustainability: a review and synthesis. For. Ecol. Manag. 122, 51-71.

Otero, M., Santos, D., Barros, A.C., Calapez, P., Maia, P., Keizer, J.J., Esteves, V.I., Lillebø, A.I. 2015. Soil properties, phosphorus fractions and sorption after wildfire in north-central Portugal. Geoderma Reg. 5, 86-95. https://doi.org/10.1016/j.geodrs.2015.04.003.

Pausas, J.G., Llovet, J., Rodrigo, A., Vallejo, V.R., 2008. Are wildfires a disaster in the Mediterranean basin? A review. Int. J. Wildland Fire 17, 713-723. https://doi.org/10.1071/ WF07151.

Pereira, V., FitzPatrick, E.A., 1995. Cambisols and related soils in north-central Portugal: their genesis and classification. Geoderma 66, 185-212. https://doi.org/10.1016/ 0016-7061(94)00076-M.

Porta, J., López-Acevedo, M., Roquero, C., 2003. Edafología para la agricultura y el medioambiente. 3rd ed. Mundi Prensa, Madrid.

Ribeiro, C., Madeira, M., Araújo, M.C., 2002. Decomposition and nutrient release from leaf litter of Eucalyptus globulus grown under different water and nutrient regimes. For. Ecol. Manag. 171, 31-41. https://doi.org/10.1016/S0378-1127(02)00459-0.

Santín, C., Otero, X.L., Doerr, S.H., Chafer, C.J., 2018. Impact of a moderate/high-severity prescribed eucalypt forest fire on soil phosphorous stocks and partitioning. Sci. Total Environ. 621, 1103-1114. https://doi.org/10.1016/j.scitotenv.2017.10.116.

Santos, R.M.B., Sanches Fernandes, L.F., Pereira, M.G., Cortes, R.M.V., Pacheco, F.A.L., 2015 A framework model for investigating the export of phosphorus to surface waters in forested watersheds: implications to management. Sci. Total Environ. 536, 295-305. https://doi.org/10.1016/j.scitotenv.2015.07.058.

Shakesby, R.A., 2011. Post-wildfire soil erosion in the Mediterranean: review and future research directions. Earth Sci. Rev. 105, 71-100. https://doi.org/10.1016/j. earscirev.2011.01.001.

Shakesby, R.A., Doerr, S.H., 2006. Wildfire as a hydrological and geomorphological agent Earth Sci. Rev. 74, 269-307. https://doi.org/10.1016/j.earscirev.2005.10.006.

Silins, U., Bladon, K.D., Kelly, E.N., Esch, E., Spence, J.R., Stone, M., Emelko, M.B., Boon, S., Wagner, M.J., Williams, C.H.S., Tichkowsky, I., 2014. Five-year legacy of wildfire and salvage logging impacts on nutrient runoff and aquatic plant, invertebrate, and fish productivity. Ecohydrology 7, 1508-1523. https://doi.org/10.1002/eco.1474

Smith, H.G., Sheridan, G.J., Lane, P.N.J., Nyman, P., Haydon, S., 2011. Wildfire effects on water quality in forest catchments: a review with implications for water supply. J. Hydrol. 396, 170-192. https://doi.org/10.1016/j.jhydrol.2010.10.043.

Smith, H.G., Hopmans, P., Sheridan, G.J., Lane, P.N.J., Noske, P.J., Bren, L.J., 2012. Impacts of wildfire and salvage harvesting on water quality and nutrient exports from radiata pine and eucalypt forest catchments in south-eastern Australia. For. Ecol. Manag. 263, 160-169. https://doi.org/10.1016/j.foreco.2011.09.002.

SNIRH (Sistema Nacional de Informação de Recursos Hídricos), 2019. .Available at. https://snirh.apambiente.pt/snirh/_dadossintese/qualidadeanuario/boletim/tabela classes.php Accessed online on September $2^{\text {nd }} 2019$.

Stein, E.D., Brown, J.S., Hogue, T.S., Burke, M.P., Kinoshita, A., 2012. Stormwater contaminant loading following Southern California wildfires. Environ. Toxicol. Chem. 31 (11), 2625-2638. https://doi.org/10.1002/etc.1994.

Sternberg, M., Shoshany, M., 2001. Influence of slope aspect on Mediterranean woody formations: comparison of a semiarid and an arid site in Israel. Ecol. Res. 16 (2), 335-345. https://doi.org/10.1046/j.1440-1703.2001.00393.x.

Thomas, A.D., Walsh, R.P.D., Shakesby, R.A., 1999. Nutrient losses in eroded sediment after fire in eucalyptus and pine forests in the wet Mediterranean environment of northern Portugal. Catena 36, 283-302. https://doi.org/10.1016/S0341-8162(99)00051-X.

Thomas, A.D., Walsh, R.P.D., Shakesby, R.A., 2000a. Post-fire forestry management and nutrient losses in eucalyptus and pine plantations, northern Portugal. Land Degrad. Dev. 11, 257-271. https://doi.org/10.1002/1099-145X

Thomas, A.D., Walsh, R.P.D., Shakesby, R.A., 2000b. Solutes in overland flow following fire in eucalyptus and pine forests, northern Portugal. Hydrol. Process. 14, 971-985. https://doi.org/10.1002/(SICI)1099-1085(20000415)14:5<971::AID-HYP4>3.0.CO;2-J.

Turco, M., Llasat, M.-C, von Hardenberg J. Provenzale, A, 2014. Climate change impacts on wildfires in a Mediterranean environment. Clim. Chang. 125, 369-380. https://doi. org/10.1007/s10584-014-1183-3.

Urbanek, E., Shakesby, R.A., 2009. The impact of stone content on water flow in waterrepellent sand. Eur. J. Soil Sci. 60, 412-419. https://doi.org/10.1111/j.13652389.2009.01128.x.

Vallejo, V.R., Alloza, J.A., 2015. Postfire ecosystem restoration. In: Paton, D. (Ed.), Wildfire Hazards, Risks, and Disasters. Elsevier Inc, pp. 229-246.

Vega, J.A., Fernández, C., Fonturbel, T., González-Prieto, S., Jiménez, E., 2014. Testing the effects of straw mulching and herb seeding on soil erosion after fire in a gorse shrubland. Geoderma 223-225, 79-87. https://doi.org/10.1016/j.geoderma.2014.01.014.

Verkaik, I., Rieradevall, M., Cooper, S.D., Melack, J.M., Dudley, T.L., Prat, N., 2013. Fire as a disturbance in mediterranean climate streams. Hydrobiologia 719, 353-382. https:// doi.org/10.1007/s10750-013-1463-3.

Viedma, O., Moity, N., Moreno, J.M., 2015. Changes in landscape fire-hazard during the second half of the 20th century: agriculture abandonment and the changing role of driving factors. Agric. Ecosyst. Environ. 207, 126-140. https://doi.org/10.1016/j. agee.2015.04.011.

Vieira, D.C.S., Malvar, M.C., Fernández, C., Serpa, D., Keizer, J.J., 2016. Annual runoff and erosion in a recently burn Mediterranean forest - the effects of plowing and time since fire. Geomorphology 270, 172-183. https://doi.org/10.1016/j geomorph.2016.06.042. 
Walsh, R.P.D., Coelho, C.O.A., Shakesby, R.A., Terry, J., 1992. Effects of land use management practices and fire on soil erosion and water quality in the Águeda River Basin, Portugal. GeoÖko Plus 3, 15-36.

Wittenberg, L., Inbar, M., 2009. Role of fire disturbance on runoff and erosion processes a long-term approach, Mt. Carmel case study, Israel. Geogr. Res. 47 (1), 46-56. https://doi.org/10.1111/j.1745-5871.2008.00554.x.
Wittenberg, L., Malkinson, D., Barzilai, R., 2014. The differential response of surface runoff and sediment loss to wildfire events. Catena 121, 241-247. https://doi.org/10.1016/j. catena.2014.05.014.

Zar, J.H., 1999. Biostatistical Analysis, 4th ed. Prentice-Hall, New Jersey.

Zavala, L.M., De Celis, R., Jordán, A., 2014. How wildfires affect soil properties. A brief review. Cuad. Investig. Geogr. 40, 311-332. https://doi.org/10.18172/cig.2522. 